\title{
Toward a feminist political ecology of household food and water security during drought in northern Nicaragua
}

\author{
Christopher M. Bacon $^{1}$ (D), Lisa C. Kelley ${ }^{2}$ and Iris T. Stewart ${ }^{1}$
}

\begin{abstract}
Few studies assess the relationship between food and water access, despite global concerns about people's inability to maintain access to both food and water. We conducted a mixed-methods comparative case study in northern Nicaragua, with smallholders from two neighboring communities that differed in water availability and institutional strength, using a feminist political ecology framework and food and water security definitions that focus on access, availability, use, and stability. We adopted a participatory approach that included: a sex-disaggregated survey in 2016; interviews, participant observation, and community-based water quality testing from 2014 to 2019; and analysis of a severe drought that occurred from 2014 to 2017. Our results suggest that uneven power relations, biophysical conditions, gender, and institutions shape food and water access, and indicate that households across both communities average 2 months of drinking water insecurity during the dry season followed by an average of 2.5 months of food insecurity early in the growing season. The average duration of lean food months was similar across communities and sex, but water insecurity lasted longer in the community that had weaker local institutions and less surface water availability. Ethnographic research helped to document uneven and gendered experiences of water access and to illustrate how they were also shaped by conflicts over water for irrigation vs. domestic uses and cross-scalar limitations in water and land governance. Although we found that gender and institutions were not strong predictors of several food and water insecurity indicators on their own, both factors influenced the terms of access, conflict, and cooperative governance needed to secure resources and well-being. Our study highlights the need for theory, methods, and field research that integrate the analysis of food and water security, and it contributes to developing a feminist political ecology approach that unifies this analysis with a focus on gender.
\end{abstract}

Key Words: Central America; community-based research; drought; feminist political ecology; food security; water security

\section{INTRODUCTION}

Despite growing global concern about rural food and water access, research assessing how food and water security relate to each other, gender, and institutions remains comparatively sparse (Wutich and Brewis 2014). The gap in research linking food and water security is compounded by a still comparatively small body of holistic, comparable research methods for assessing household and individual experiences of water security (Jepson et al. 2017, Young et al. 2019). Additional challenges to assessing food and water access include explaining how experiences of stress and material scarcities are produced through the intersection of existing social vulnerabilities and exposures to hazards operating across spatial, institutional, and temporal scales (Shinbrot et al. 2019). Smallholders and allied organizations continue to seek strategies to reduce their risks of food and water shortages in the face of multiple hazards such as climate disruption, political economic shocks, and, more recently, pandemics.

Here, we use an interdisciplinary, mixed-methods approach rooted in feminist political ecology (FPE; Rocheleau et al. 1996, Elmhirst 2011, Sundberg 2017) to understand the connections between food and water security, gender, and institutions in northern Nicaragua. FPE has been used to unpack assumptions about the uniformity of resource access within and across households and to reveal the diverse individual experiences shaped by uneven gender relations (Radel et al. 2013, Bezner Kerr 2014, Harris et al. 2017). FPE studies also critically examine how meanings about nature, gender, and associated biophysical processes are co-produced and altered over time (Nightingale
2011). Several FPE studies have explained how gendered experiences of food insecurity relate to uneven patterns in resource access, power dynamics, global climate change, migration, and agrarian change (Bee 2016, Radel et al. 2018). In the context of water security, FPE studies have analyzed disparities in labor routines, psychosocial stress, and access to safe drinking water and sanitation, and have linked these local patterns to uneven participation in governance and the influence of global change (Sultana 2011, Truelove 2011, Ranganathan and Balazs 2015, Harris et al. 2017). However, to the best of our knowledge, researchers have not developed an FPE of both food and water security.

Based on entitlement theory pioneered by Drèze and Sen (1991), food security interpretations evolved from a narrow focus on availability (prevalent from the 1940s to the 1980s) to a fourdimensional analysis of availability, access, use, and stability (Pinstrup-Andersen 2009). Food security is now seen to exist "when all people, at all times, have physical and economic access to sufficient, safe and nutritious food that meets their dietary needs and food preferences for an active and healthy life" (FAO et al. 2019). Nutritional security is an increasingly important component of food security that focuses on food diversity, quality, and preparation, as well as individual health status, sanitation, and access to care (High Level Panel of Experts 2017). Although there are significant differences in the needs, uses, access, and storage of food vs. water, the four pillars approach can also be applied to water security, contributing to a framework for integrated analysis (Young et al. 2021).

${ }^{1}$ Department of Environmental Studies and Sciences, Santa Clara University, ${ }^{2}$ Department of Geography and Environmental Sciences, University of Colorado Denver 
In recent decades, the concept of water security has similarly evolved from narrow and technocratic approaches to encompass social, economic, and political considerations at multiple scales (Cook and Bakker 2012). The United Nations defined water security as the "capacity of a population to safeguard sustainable access to adequate quantities of acceptable quality water for sustaining livelihoods, human well-being, and socio-economic development, for ensuring protection against water-borne pollution and water-related disasters, and for preserving ecosystems in a climate of peace and political stability" (United Nations Water 2013). However, what constitutes "adequate" water security (and how best to assess it) remains debated, though several recently published studies have contributed meaningful advances (Brewis et al. 2020, Wutich et al. 2021, Young et al. 2021). We define individual and household water security as existing when all people at all times have physical and economic access to water that is sufficient and safe (in quantity and quality) for drinking, cooking, bathing, and cleaning needs.

We next review insights from FPE and identify the relevance of such an approach to a joint analysis of household food and water security. We then describe the combination of participant observation, interviews, focus groups, household surveys, and hydroclimatic methods used within a comparative case study of smallholder experiences of food and water security in two villages in northern Nicaragua. Our analysis focuses on understanding the implications of a severe drought that occurred from 2014 2016, and how local institutions, gender, and power inequalities influenced food and water access relations. We also analyze the cross-scalar nature of food and water security challenges in discussing an ongoing water access conflict shaped by upstream water appropriations for commercial potato farming. In closing, we reflect on how future analyses could more fully realize an FPE approach to food and water access challenges.

\section{TOWARD A FEMINIST POLITICAL ECOLOGY OF FOOD AND WATER SECURITY}

We engage FPE as an approach that allows researchers to examine human-environmental change and conflict critically by asking questions about the uneven power relations mediating resource access, governance, and control across multiple scales (Watts 2000, Elmhirst 2015). FPE studies also focus on how the meanings and materialities of both gender and the environment are mutually constructed, changed, and co-produced over time (Nightingale 2020). Here, FPE enables us to assess the coproduction of social difference, environments, and food and water insecurities.

Over time, FPE scholarship has expanded beyond its initial focus on how gender relations, understood as culturally defined malefemale sex roles, structure access to particular types of knowledge, space, resources, and socio-political processes (compare Carney 1993, Rocheleau et al. 1996, Freidberg 2001 as cited in Nightingale 2006:169). Subsequent FPE scholarship has also shed light on the construction of social difference and environments (or socionatures), the importance of nature's agency, and how gender intersects with race, class, caste, and other identities within broader historical politico-economic and ideological power relationships (Nightingale 2020, Sultana 2021). We use the notion of gendered socio-natures to reference conceptual and empirical approaches that recognize that: (1) human-nature relations are both social and gendered; (2) gender, nature, and society relations are also relations of power; and (3) the study of gender, nature, and society is linked to sustainability and gender justice goals (Burandt and Mölders 2017).

Scholars addressing the many relationships connecting smallholder farmers' food security and water security using a FPE approach have also started to examine how these outcomes intersect with gender dynamics, resource management, and local institutions (e.g., Bezner Kerr 2014, Alston and Akhter 2016, Fehr and Moseley 2019). FPE studies have also examined the intersections between water security, gender, and environmental governance (Truelove 2011, Harris et al. 2017, Adams et al. 2018). Though we found at least one exception (i.e., Fehr and Moseley 2019), an integrated approach to food-water analysis within FPE remains rare. This rarity suggests that developing the basis for such an approach within FPE can contribute a richer theorization of how food and water securities and gender relate. While the fullest elaboration of such an approach requires addressing dynamics of intersectionality and postcoloniality (Elmhirst 2015, Sultana 2021), we begin by drawing on the strengths of FPE in assessing gendered labor, access relations, and food and water insecurity (Rochaleau et al. 1996, Harris et al. 2017).

FPE offers particular traction in exploring questions of resource access because it situates gender as being constitutive of a "bundle of powers" structuring people's abilities to secure and maintain benefits (e.g., Ribot and Peluso 2003:154). Such an emphasis is also productive in analyzing food and water access, given its linkages to entitlements and capabilities approaches (two approaches long applied to questions of food and water security). Entitlements comprise "the set of alternative commodity bundles that a person can command in society using the totality of rights and opportunities he or she faces"(Sen 1984:497), and capabilities are defined as "what people are actually able to do and be" (e.g., good health, adequate nourishment, and freedom of mobility and security; Nussbaum 2011).

Finally, FPE offers concepts to help explain how people negotiate gendered entitlements and access relations through local institutions, focusing on how institutions and gender relations influence the power-laden conflicts that shape the terms of access to clean water and sufficient food. We define institutions as the formal (e.g., laws and regulations) and informal (e.g., customary property rights, relationships with traders) norms and practices, including organizations (e.g., churches, cooperatives, and governments in all of its forms) and structured recurrent relationships (e.g., shared community work) that coordinate collective action (Poteete et al. 2010). Thus, institutions help deliver external resources (Agrawal 2010), manage resources, determine access relations, influence responses to changing resource availability and quality, and establish and regulate norms surrounding property rights (Ostrom 2005).

Inspired by work in FPE, we also provide initial analysis of how gendered socio-natures are being constructed across multiple scales (body, household, community, watershed, and beyond), focusing particularly on issues related to women's use of downstream water resources. While we cannot fully develop such an analysis here, we return, in closing, to reflections on how future work could expand on these ideas. 


\section{STUDY CONTEXT AND RESEARCH QUESTIONS}

\section{Local institutions for food and water security in Nicaragua}

Access to food and water in rural northern Nicaragua is often tenuous and involves significant labor, time, and, often, money. Although poverty in the country has decreased, official estimates in 2017 found that $25 \%$ of the population lived in poverty (World Bank 2018). Food insecurity (particularly seasonal hunger) remains a persistent challenge (Bacon et al. 2021). Although some rural communities may have sufficient capital to install wells, pumps, and improved water systems, many rural households rely on common property access to water from local streams, wells, or public spigots.

In Nicaragua and other Latin American countries, agricultural cooperatives and rural water committees are key communitybased institutions for managing access to land, food, and water, particularly in the context of decentralization (Larson and Soto 2008). In 2014, > 100,000 farmers were affiliated with cooperatives in Nicaragua, with cooperatives controlling approximately $35 \%$ of coffee exports (Utting et al. 2014). Cooperative functions have evolved from the 1980s focus on agrarian reform and civil defense during wartime to become multiservice providers coordinating marketing, credit, and local development (Bacon 2015, Wilson 2015).

Nicaragua's Potable Water and Sanitation Committees (Comités de Agua Potable y Saneamiento, hereafter CAPS) supplement the focus of rural cooperatives on agricultural entitlements with a specific focus on improving water access. Since the late 1970s, CAPS have been responsible for managing small-scale water infrastructure in communities typically $<500$ households in rural and semi-rural regions of the country (Romano 2019). The General Water Law (Ley 620), passed in 2007 and updated by the Special Law for Potable Water and Sanitation Committees (Ley 722 ) in 2010, legally formalized the CAPS, establishing rights. Justified by reference to the common good, natural rights, and Madre Tierra (mother Earth), Law 722's Article IV explicitly prohibits the privatization of water resources (LaVanchy et al. 2017). It also mandates that local community CAPS hold regular general assemblies that are open to all adult community members and elect a leadership board (Ley 722). Although CAPS leadership offices are open to all committee members in "good standing," several of Nicaragua's laws promote equal participation of women (and men) in elected office, and previous research suggests that consultants helping CAPS establish their bylaws often encouraged them to include a line about women's equal participation in leadership positions (Alaniz 2021). Once legally constituted, CAPS can collect fees from members, invest in new water systems, develop local policies on water management and use, and develop agreements with other institutions (Romano 2019).

\section{Research question and hypotheses}

We started this field research during a severe drought that affected northern Nicaragua from 2014-2016, and our expectation was that the drought would significantly exacerbate food and water insecurities in the study area. Drought would generally decrease the water availability and quality (Mosley 2015), diminishing stream flows and increasing household water insecurity, as most village water systems in northern Nicaragua's mountains rely on surface water (Romano 2019), and water quality often decreases with less flow. In these communities, smallholder farmers rely on rain-fed agriculture for their annual corn and bean harvests and for sustaining yields of key cash crops (e.g., coffee). Thus, the seasonality of precipitation influences crop planting cycles and recurring periods of seasonal hunger. Seasonal hunger is common for resource-constrained rural residents, usually lasts for one to three months during "normal" precipitation years (Bacon et al. 2017, Niles and Brown 2017), and would be expected to increase under drought. Lower incomes due to crop harvest failures and less off-farm work could decrease incomes, food purchases, and household dietary diversity, which is an indicator of nutritional security and diet quality (Sibhatu et al. 2015).

We also expected to find that participation in a strong farmer cooperative would enable greater food security by improving access to credit and better markets, much like a robust water committee could enable greater water security by facilitating responses to drought and maintaining vital water infrastructure. Although Nicaragua's gender equality indices have improved from 2010 to 2017, implying a degree of female empowerment (Nguyen et al. 2020), traditional gender roles still persist in many cases, and women generally do more work fetching water and preparing food (Galiè et al. 2015, Gonda 2016, Godek and García 2018). Women also continue to face greater challenges than men in securing land titles (Deere et al. 2012). Thus, we anticipated that female respondents would report higher incidences of food and water insecurity during the 2014-2016 drought (Segnestam 2009). The broader literature on gender and governance also suggests that in most cases, women's roles in governing local environmental institutions would be more limited than those of men because of histories of discrimination, partriarchy, and political economic exclusion (Cleaver and Hamada 2010, Grabe 2010, Harris et al. 2017).

In this context, we asked: How do institutions and gender relations influence local experiences of food and water insecurity during a severe drought? We hypothesized that the drought would increase food and water insecurity for all individuals, as measured by the reported frequency and duration of periods of seasonal food and water scarcity, the severity of coping responses, and declines in the quality of accessible food and water reported in the two communities. We also hypothesized that gendered power inequalities in resource access would contribute to women in both communities reporting more food and water insecurity and less influence over the management and governance of common resources. Finally, we hypothesized that stronger local institutions, in the form of agricultural cooperatives and water committees, would be connected with greater food and water security.

\section{METHODS}

To address our research question, we employed interdisciplinary research methods ranging from an analysis of historical climate signals to sex-disaggregated survey analyses and participant observation. Previous studies in the region (Bacon et al. 2017) and studies of community-based resource management (Delgado-Serrano et al. 2017) suggest that participation in coproducing research can improve resource management (Chevalier and Buckles 2019). We embedded our specific methods within a broader community-based participatory action research framework, focusing on two northern Nicaraguan smallholder 
Fig. 1. Locations of case study areas in the coffee-growing regions of northern Nicaragua. Community and co-op boundaries were mapped with help from local residents.

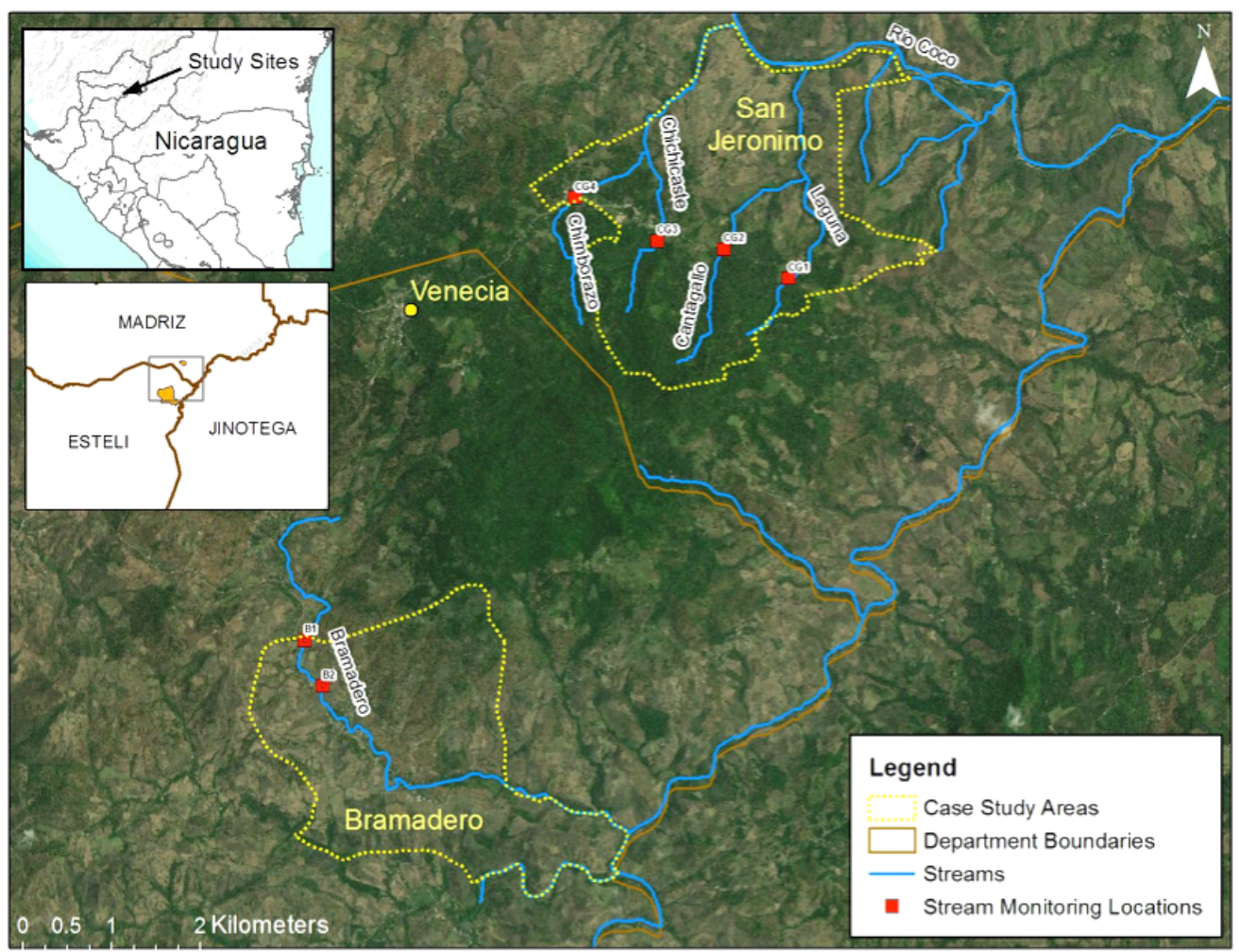

farming communities where the first author has long-standing ethnographic work and relationships.

\section{Comparative case study communities}

The two case study communities are characterized by similar agricultural livelihoods and different local institutional capacities for accessing food and water. San Jeronimo (SJ) residents are affiliated with a strong primary cooperative that holds a 2000-ha collective land title, including $>600$ ha of forested and shade coffee (Coffea arabica) production areas (Fig. 1). SJ's co-op was formed $>25$ years ago and has an elected board, monthly meetings, and a functional accounting system. Approximately $35 \%$ of co-op members are female. Although men dominated coop governance in the early years, the recent 10 years have seen increasing female participation on the board; at the time of this research, the co-op's vice-president was a female who was later elected as co-op president. The community has $>1000$ households. It works through PRODECOOP, a powerful secondary cooperative comprising 35 primary co-ops, to offer access to organic and fair-trade coffee markets, credit, and development and gender equity programs for its 130 members. The SJ co-op has also partnered with PRODECOOP and others to address food insecurity through crop diversification and a coop-led seed bank and grain storage center. In contrast, a strong primary cooperative is not present in Bramadero (B), the other case study community. Bramadero is a rural agricultural community that is best known for its red bean (Phaseolus vulgaris) production and its location along a well-maintained dirt road connecting two mid-sized Nicaraguan cities.
Both communities have CAPS that take responsibility for maintaining a system of pipes and storage tanks to channel water from higher elevation springs into settlement areas. These committees consist of five elected members, including three men and two women in each. Men hold the leadership positions in both cases and generally speak more during group interviews, but unlike SJ, B has a female CAPS coordinator who speaks more often in meetings and emerged as one of the leaders advocating for this CAPS. The SJ CAPS holds regular meetings and is closely connected to the co-op, with several members occupying key positions in both institutions. It has also responded to inconsistent water flow by finding new feeder streams to channel into the water system. The B CAPS was not formally registered at the time of the study (2016), but did hold occasional meetings and cleanup days to manage their outdated system, initially designed in 1984. Nonetheless, the B CAPS had fewer ties to other organizations and extra-community relationships than the SJ co-op used when it worked with PRODECOOP's coffee buyers to secure significant investment into improved local water infrastructure in 2014, coffee replanting, and the food security initiatives described above.

Livelihoods and food and water security in both communities are largely structured around access to agricultural lands, common property resources (e.g., surface water), and subsistence and market-oriented crop production, such as coffee. Participant observation shows that residents in both communities rely on upstream surface water for drinking water systems, and use stream water for cleaning, bathing, washing clothes, washing coffee, 
watering livestock, and, in limited cases, irrigation. Participatory mapping suggests greater surface water availability from the four streams in SJ vs. the single one in B (Fig. 1). Farmers predominantly rely on rain-fed production in northern Nicaragua (Bacon et al. 2017). Although irrigated small-scale horticultural production (e.g., bell peppers and tomatoes) has expanded in the last 15 years, extensive irrigation withdrawals in mountain farming communities are thought to be uncommon (Michelson et al. 2012). The landscape of low mountains in the study area (Fig. 2A) includes native pine tree stands, semi-humid broadleaf tropical forests, shade-grown coffee, mixed-use pasture, and fields for milpa (mostly corn-and-bean fields; Fig. 2B) and vegetable production (Kelley et al. 2018).

Fig. 2. Photographs of the two study area landscapes. (A, top) San Jeronimo landscape with steep slopes down to Rio Coco. Shade coffee is at the right background; milpa in early stages of development, with corn and beans planted simultaneously, is in the foreground. Credit: Misael Rivas. (B, bottom) Bramadero community landscape. Milpa to the right shows corn drying and beans climbing the corn; lower slopes, pastures, and forests are in the background. Credit: Lisa Kelley.

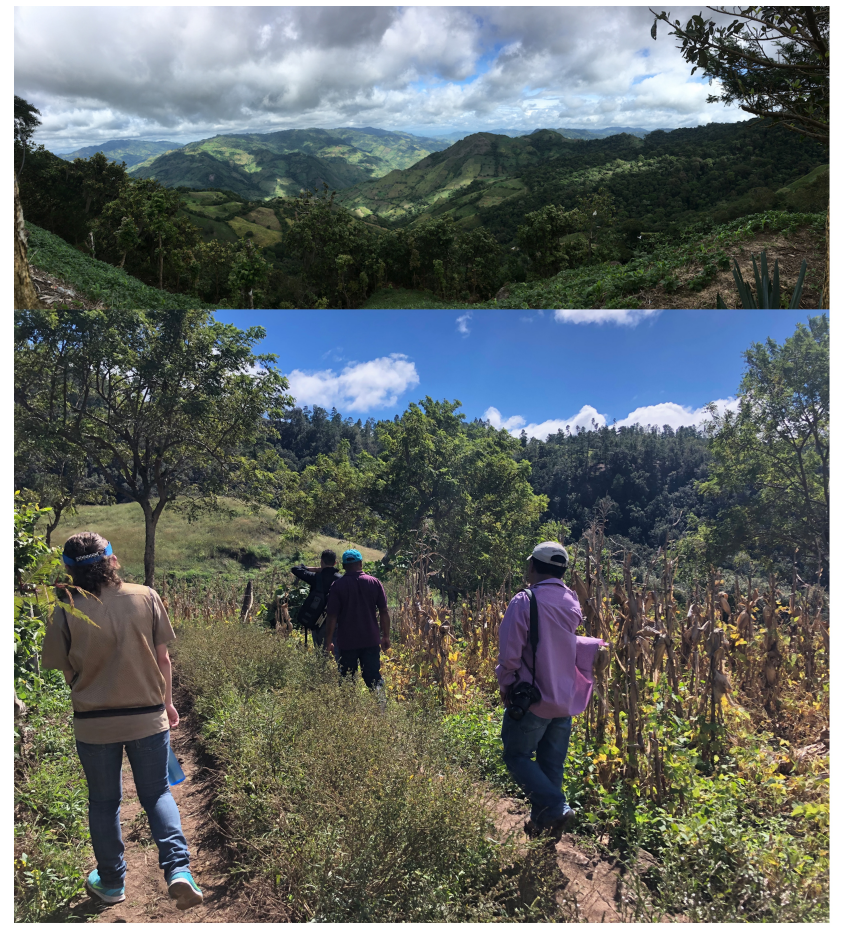

Most household livelihoods rely on rainfed milpa (Fig. 2B) and coffee production. Producers work a comparatively small area, managing on average $2.2 \pm 1.4$ ha of land per household, with on average $0.7 \pm 0.3$ ha held in milpa and $1.0 \pm 0.6$ ha in shade coffee per our survey data. Similar to elsewhere in Mesoamerica, milpa production remains key for household food security and identity and often contributes to farmer incomes (Isakson 2009). Many farmers report that $\geq 50 \%$ of their annual food consumed is grown on their farm, and bean sales are a top source of income. Corn and bean production are more important in $\mathrm{B}$ than in $\mathrm{SJ}$; in $\mathrm{B}$, the three most important income sources are bean sales, local businesses, and corn sales and other activities. In SJ, coffee is the top income source, followed closely by bean sales. Previous studies conducted in 2014 that included our study area found that a majority of smallholders reported coffee as the most important income source (Bacon et al. 2017). However, coffee rust damage and stable bean prices since the 2011 outbreak of coffee leaf rust may have contributed to the greater economic importance of beans and other crops. In addition to agricultural production, $49 \%$ of the respondents reported at least one off-farm income source, which is the primary income for $33 \%$ of all households. Common off-farm activities include small businesses or day labor, with $<5 \%$ of all individuals able to access salaried work.

\section{Research period and approaches}

To address our research question, we conducted interviews and focus groups, a sex-disaggregated survey, a community-based water monitoring initiative, and an analysis of recent precipitation as a proxy for water stress in the region. Although drawing on contextual understandings from $>15$ years of research in this study region (Bacon 2015), the primary field research reported here took place from 2014-2019, including a survey in 2016, and qualitative research and water monitoring throughout this period, as well as a comparison of historical precipitation records to recent patterns to assess the drought. As part of our communitybased participatory action research approach (Chevalier and Buckles 2019), community promoters helped design and conduct surveys, collected monthly water monitoring data, and were involved in interpreting results. In addition to Santa Clara University faculty and students, our research team included staff from a long-term partner organization, the Association for the Social Development of Nicaragua (ASDENIC). ASDENIC is a regional education, research, and local development non-profit organization that helped organize the survey enumerator training, convene focus groups, connect to the water committees, and establish the community-based water quality network.

Our analysis began with a focus on the drought conditions mediating food and water access using the Climate Hazards Group InfraRed Precipitation with Station data daily precipitation dataset from 1981-2017 (Funk et al. 2014). These data were used to calculate the time series and trends of average monthly precipitation, total annual precipitation, and the MayJuly and August-October three-month standard precipitation index (SPI; McKee et al. 1993) over time in both communities. SPI is a widely used index to measure and compare drought conditions; scores represent the number of standard deviations by which observed cumulative precipitation deviates from the climatological average. In categorizing drought, we follow established practice, whereby $-1 \geq \mathrm{SPI} \geq-1.49$ refers to moderate drought, $-1.50 \geq \mathrm{SPI} \geq-1.99$ to severe drought, and $\mathrm{SPI} \leq-2.0$ to extreme drought.

We also conducted a sex-disaggregated household survey in the two communities. We used prior interviews and existing surveys (e.g., Garlick 2015, Bacon et al. 2017) to design our survey, and piloted questions with community promotores (promoters) during field methods and ethics training. Most survey questions focused on: (1) demographic information; (2) household characteristics, including livelihood capabilities, entitlement, and institutional affiliations; and (3) the terms and experiences of food and water access. Food security questions assessed months of inadequate 
food provision or lean months (Niles and Brown 2017, Anderzén et al. 2020) and the frequency of coping responses used in the month before the survey (e.g., skipping meals, eating less preferred foods, or borrowing money; Maxwell et al. 2013). To understand the quality of accessible food, we calculated household dietary diversity scores based on reports from surveyed individuals about the average number of 14 food groups (with culturally adjusted examples) consumed daily during the prior week (Kennedy et al. 2011). Water security questions assessed households' primary and secondary water sources for drinking, cooking, bathing, and irrigation, and assessed months of perceived water scarcity (World Health Organization and United Nations Children's Fund 2006). Although water quality was assessed through the survey (i.e., perceptions of quality), we also used participant observation and community-based water monitoring to assess directly the quality of water in local streams. To this end, our team trained residents to conduct monthly tests of stream and potable water for coliform and Escherichia coli bacteria using EC 3M Petrifilm plates (3M, St. Paul, Minnesota, USA) that identify contamination within a 48-h incubation period (Pearson et al. 2008). Tests were conducted at 14 locations in SJ and 7 locations in B that included source streams, tanks, and household water taps. Water quality data were collected from 2013-2017 and were shared with members of both communities at a follow-up workshop in 2019.

The research population for this survey was small, consisting of 130 members (most representing their household) affiliated with a coffee-producing agricultural marketing and multiservice co-op in $\mathrm{SJ}$, and a list of adults from a village census of 115 households in B. We used these lists to identify a random sample of $15-20 \%$ of member households, aiming for equal representation of men and women in each community and with the goal of enhancing the value of the small sample by selecting matched male and female respondents from within the same households. Community promotores conducted the surveys with individual male or female respondents, totaling 19 females and 21 males in SJ, and 19 females and 19 males in B for a total of 19 matched households in each village. Given that the study is limited by a small survey sample size, we discuss results in averages and percentages rather than in terms of statistically significant differences.

We also draw heavily on ethnographic fieldwork, including participant observation during multiple field visits, 12 focus groups, and 20 key informant interviews conducted during 2014 2019. Focus groups each comprised 5-12 adult community members, including co-op and CAPS leaders. Several focus group discussions were also separated by sex to facilitate dialogue about sensitive issues and inequalities. We also drew on this qualitative work, consultations with local experts, and a set of survey questions to briefly characterize key local institutions (e.g., water committees, the co-op, and common property) and the relative capacity for management. We included interview questions about the degree of social cohesion within local institutions (e.g., bonding social capital) and links to other communities or external agencies (e.g., linking social capital; Pretty and Ward 2001, Ramirez-Sanchez and Pinkerton 2009), as well as survey and interview questions about community norms and rules for the use and management of streams, water systems, and forests (Tucker 1999, International Forestry Resources and Institutions 2013). In addition, we conducted two focus groups with leaders of a third community, Venecia (V), where upstream agricultural water uses directly intersect with water and food security in B.

These ethnographic findings supplement and inform hydroclimatic data and our small survey sample in a variety of ways. For instance, focus group discussions were used to develop localized understandings of the severity of reported coping responses, following established methods for ranking responses (e.g., going without food or water, spending savings) in terms of their severity on a scale of 1 to 4 (wherein higher scores suggest less preferred coping responses and more challenging circumstances; Maxwell et al. 2013). We extended and adapted these same methods to assess water insecurity coping strategies, designing household water security discussions to parallel food security discussions by focusing on the temporality of access, perceptions of quality, and the severity of stress-related coping responses. A list of potential coping responses (e.g., conflicts over water access, bathing in less preferred places, going to bed thirsty) were drawn from earlier water security studies (Hadley and Wutich 2009, Stevenson et al. 2016) and then expanded and culturally adapted.

Finally, we draw on participants' reflections about their village water monitoring activities and focus group discussions to analyze how community-based efforts are situated within uneven multiscale power dynamics that influence how marginal communities access resources, navigate conflict, represent themselves, and seek support (Larson and Soto 2008). A challenge for us with respect to our original research design was the discovery of a cross-community conflict with $\mathrm{V}$ in 2016, which emerged as a key territory influencing patterns of uneven water access, especially in B (Fig. 1). After conducting the survey and first round of focus groups in 2017, subsequent research activities included focus groups in $\mathrm{V}$. We also draw on two workshops about adaptation, food security, and water security co-organized with ASDENIC and conducted with representatives from 11 village water communities and two co-ops in the broader Cantagallo area in July and December 2019 that provided an opportunity to update initial study findings, including our analysis of the crosscommunity water conflicts.

\section{RESULTS}

\section{Climate variability and drought severity}

Recurrent periods of seasonal hunger and water insecurity in northern Nicaragua are influenced by drought and rainfall variability, water infrastructure, and multiple socioeconomic factors such as access to land or food prices (Bacon et al. 2017, 2021). The region is characterized by a mid-summer droughtdominated bimodal precipitation pattern, with the first rainy period peaking in June, the second in September-October, and a decrease in rainfall usually between late June and early August (Fig. 3A; Maurer et al. 2017). The timing and amount of monthly precipitation may differ substantially between years (Fig. 3A), which influences planting cycles. Mean annual precipitation over the 1981-2017 period is $\sim 700 \mathrm{~mm} / \mathrm{yr}$ in B and $\sim 800 \mathrm{~mm} / \mathrm{yr}$ in SJ (Fig. 3B).

Although alternating cycles of dry conditions and copious precipitation are the norm in the region, drought conditions from 2014-2016 spanning both the wet and dry seasons were 
Table 1. Lean food and water months and coping responses statistics for both communities combined, and by community and sex. Source: Sex-disaggregated survey.

\begin{tabular}{|c|c|c|c|c|c|c|c|}
\hline \multirow[b]{2}{*}{ Statistic } & \multicolumn{3}{|c|}{ Full sample } & \multicolumn{2}{|c|}{ San Jeronimo community } & \multicolumn{2}{|c|}{ Bramadero community } \\
\hline & $N$ & Mean & $\mathrm{SD}^{\dagger}$ & Female & Male & Female & Male \\
\hline Lean food months & 78 & 2.5 & 0.8 & 2.4 & 2.4 & 2.5 & 2.6 \\
\hline Food insecurity coping index & 78 & 4.9 & 4.3 & 4.3 & 6.3 & 4.6 & 4.3 \\
\hline Lean water months (drinking) & 78 & 2.0 & 2.5 & 0.9 & 1.0 & 3.0 & 3.2 \\
\hline Lean water months (cooking) & 78 & 2.4 & 3.6 & 0.6 & 0.9 & 4.4 & 3.8 \\
\hline Lean water months (bathing) & 78 & 2.4 & 3.3 & 1.5 & 1.5 & 3.7 & 3.0 \\
\hline Water insecurity coping index & 78 & 3.0 & 4.1 & 2.9 & 2.9 & 3.1 & 3.3 \\
\hline
\end{tabular}

${ }^{\dagger}$ Standard deviation.

particularly severe. Total annual precipitation was extremely low ( $\sim 550 \mathrm{~mm} / \mathrm{yr}$ ) over a two-year period (Fig. 3B), making this the longest recorded period with the overall lowest amounts of annual precipitation for both communities. The SPI index for May-July, corresponding to the first milpa planting, was lower for the 20142016 drought than during any other time over the preceding 36year period (Fig. 3C). The SPI for August-October, corresponding to the second planting cycle, was one of the four lowest since 1981 (Fig. 3D). Overall precipitation during the first and second parts of the rainy season was the lowest on record, resulting in extremely high water stress in both communities. Notably, although B generally experiences less precipitation than SJ (Fig. 3B), SJ experienced greater relative water stress during both the first and second rainy seasons during the drought (Fig. 3C,D).

Fig. 3. Precipitation variability in the two study communities from 1981 to 2017. (A) Average monthly precipitation (PPT) over the study period. Black lines indicate monthly minimum and maximum values. (B) Total annual PPT. Horizontal lines indicate means over the study period. (C) Standard precipitation index (SPI), a standard drought index, for MayJuly (MJJ). (D) SPI for August-October (ASO).

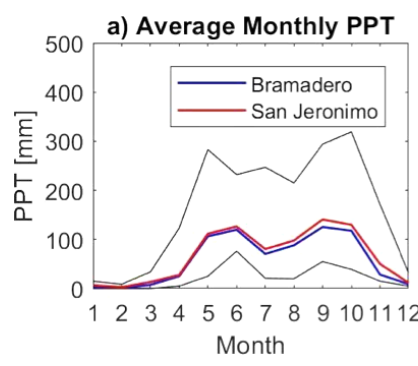

c) SPI for MJJ
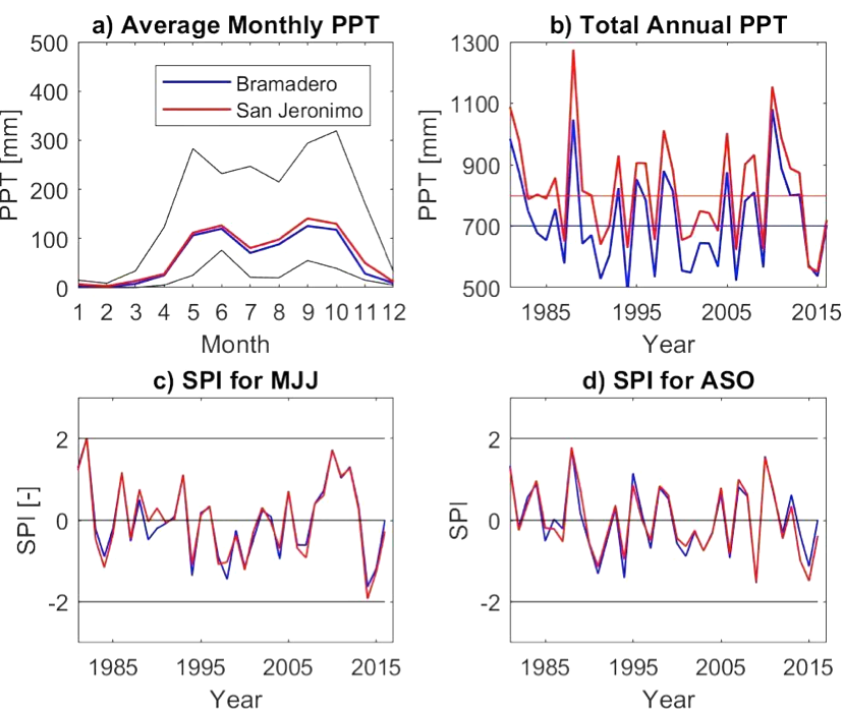

d) SPI for ASO

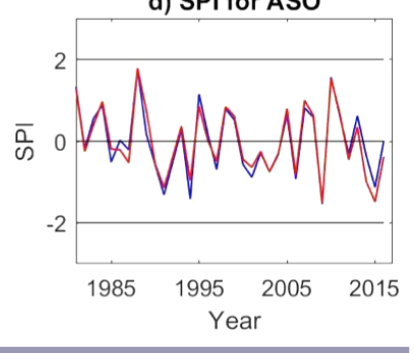

Seasonal food and water insecurity exacerbated by drought

Survey results regarding food and water insecure months indicate that $97 \%$ and $87 \%$ of respondents experienced at least one lean food or water month, respectively, during the 2014-2016 drought. The mean \pm standard deviation number of food-insecure months across all respondents was $2.5 \pm 0.8$ mo. Lean water months for drinking, cooking, and bathing were $2 \pm 2.5,2.4 \pm 3.6$, and 2.4 $\pm 2.4 \mathrm{mo}$, respectively. More than $80 \%$ of respondents reported gaps in food access in June and July; $25-38 \%$ of respondents also reported water shortages from January to May, months coincident with the dry season and low water availability (Fig. 4). Our comparative analysis asking about coping responses to current vs. past hazards found that residents considered the 2014-2016 drought to be at least as severe as Hurricane Mitch (1998), previous droughts (2007-2009), and the ongoing coffee leaf rust outbreak. These results are further corroborated by a recently published study of farmers in the same area that included surveys conducted in 2014 and 2017 (Bacon et al. 2021). In response to our first research question, this evidence, coupled with the data in Table 1, suggests that the drought's impacts on food and water security in the study communities were severe and similar to previous major climate-linked hazards, amounting to four to seven contiguous months of food or water stress for many households (Fig. 4). This combined assessment of food and water insecurity extends the well-documented hunger season, which often spans two to three months in this region, and is immediately preceded by a season of water insecurity in these two mountain communities.

The surveys and interviews also suggest that concerns about the stability of food and water access are compounded by concerns surrounding quality. When asked about their perceptions of food quality, one respondent stated, "Bad [quality] because it is exposed to pollution." A second stated, "Many venomous [toxic] chemicals are used on the [purchased] vegetables." Respondents also connected the lack of quality to high food prices and low bargaining power, with one person stating, "It's very important that we can find basic goods in the pulperías [village-level storefronts, usually built into a resident's house], but no one regulates the prices." For the week preceding the survey, respondents reported eating four to five food groups daily, a relatively high dietary diversity score compared to smallholders in some countries (e.g., Nyantakyi-Frimpong 2017). Respondents with a high number of lean food months, however, were less likely to consume culturally preferred foods such as corn or beans, indicating food stress despite relatively high dietary diversity 
Fig. 4. Reported water and food lean months by stress type, sex, and community. (A) Percent of farmers reporting lean food months and lean water months in Bramadero. (B) Number of farmers reporting lean food months and lean water months in Bramadero. (C) Percent of farmers reporting lean food months and lean water months in San Jeronimo. (D) Number of farmers reporting lean food months and lean water months in San Jeronimo. Source: Sex-disaggregated household survey.
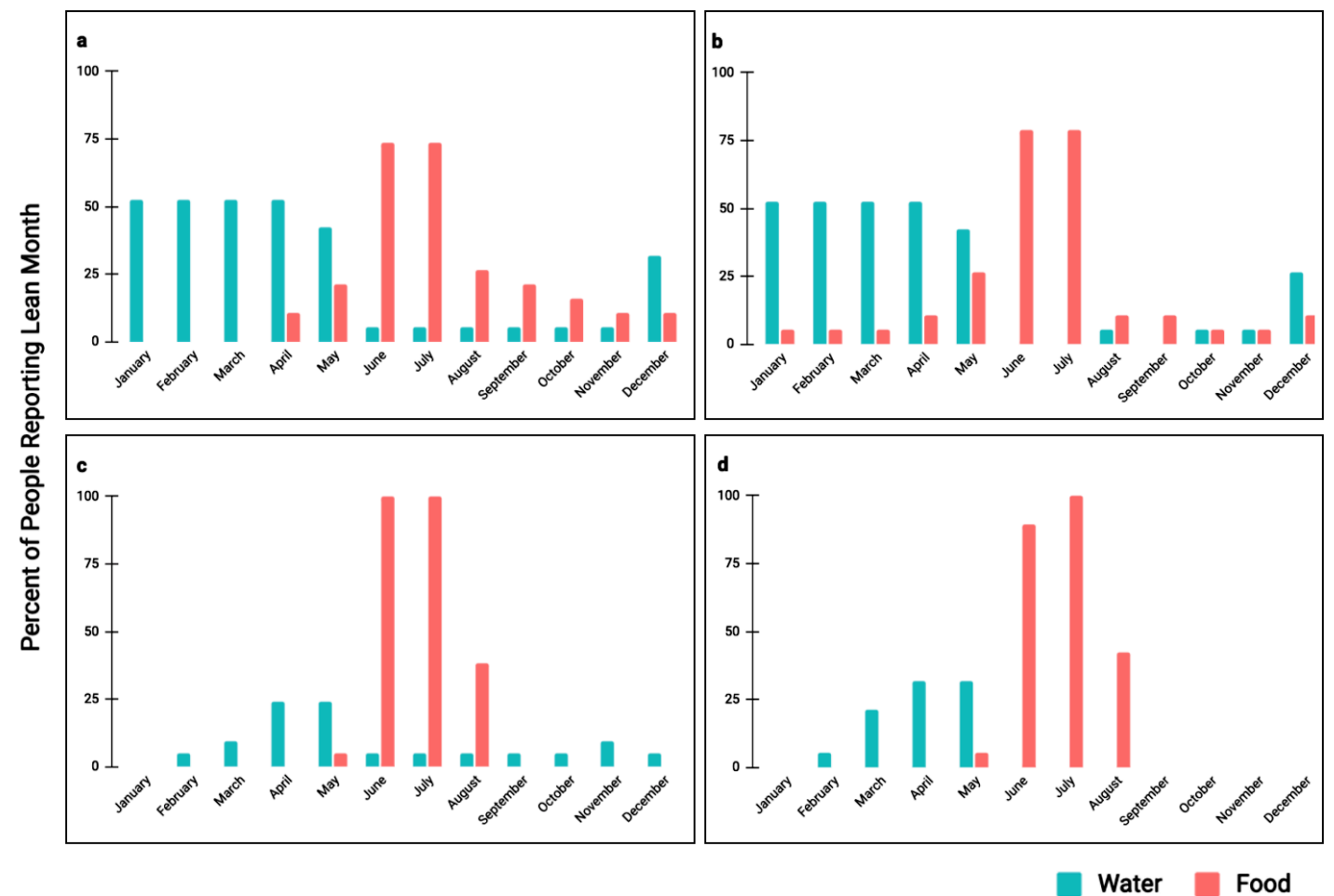

scores. Focus group discussions suggest that other coping mechanisms included reducing protein consumption by incorporating a larger share of guineo (plantains), yucca, and malanga during these times.

More than $90 \%$ of respondents also worried about water quality at least once in the year prior to taking the survey in July 2016. These data are corroborated by evidence that demonstrates the periodic presence of both $E$. coli and coliform bacteria at levels above World Health Organization drinking water standards. As would be expected, contamination was higher in streams than in water system tanks and taps in SJ and B (Fig. 5A-D). Both $E$. coli and other coliform bacteria levels were higher in SJ streams compared to $\mathrm{B}$, but results show that disinfection of the water systems effectively reduced $E$. coli by the time the water arrived at the household tap in both communities. Coliform bacteria, however, are present in household tap water, and B public taps were found to contain elevated levels of both E. coli and coliform, indicating multiple pathways for contamination to enter water supplies.

\section{Roles of gender and institutions in mediating food and water access}

The sex- and community-disaggregated survey provides one way to examine differences in food and water access with respect to gender and community (a proxy measure for access to strong local institutions). These data suggest that experiences of lean food and water months correspond more strongly with community distinctions than gender distinctions (Table 1). In particular, although men and women within the same community generally reported the same average number of lean food and water months, respondents in $\mathrm{B}$, the community with weaker local institutions, less water availability, and lower access to improved water infrastructure, reported a higher number of average lean water months than did respondents in SJ (Fig. 4, Table 1). Interestingly, despite the SJ co-op's efforts to improve food security, average lean months across the two communities were roughly equal, and men in SJ reported the most severe food insecurity coping indices of any group (Table 1).

A comparative analysis of the responses underlying the coping scores complements our assessment of seasonal food and water stress by helping to understand community-scale distinctions in the severity of the drought-specific responses (Table 2). The responses suggest that the less severe food insecurity coping responses (e.g., reducing expenditures and increasing the harvest of wild foods) were generally more common than those respondents considered to be more severe (e.g., selling assets). Nonetheless, $>50 \%$ of respondents in SJ reported spending savings to cope with the drought (Table 2A), whereas more respondents in B sought help from friends or family members, a response ranked within focus groups as being less severe than the liquidation of assets or savings (although this potentially also reflects the fact that people in $\mathrm{B}$ had fewer savings to liquidate). 
Fig. 5. (A-D) Average coliform and Escherichia coli bacterial contamination in streams and drinking water from 2015 to 2017. (A) E. coli concentrations in stream and water system samples. (B) Coliform bacteria concentrations in stream and water system samples. (C) E. coli concentrations in drinking water tap samples. (D) Coliform bacteria concentrations in drinking water tap samples. Red = San Jeronimo community, blue $=$ Bramadero community. Dashed vertical lines indicate World Health Organization (2011) safe drinking water guidelines of $<1$ coliform or E. coli bacteria per $1 \mathrm{~mL}$ water. Source: Community-based monitoring. House data in (C) and (D) were shared by ASDENIC and collected in 2013-2014.
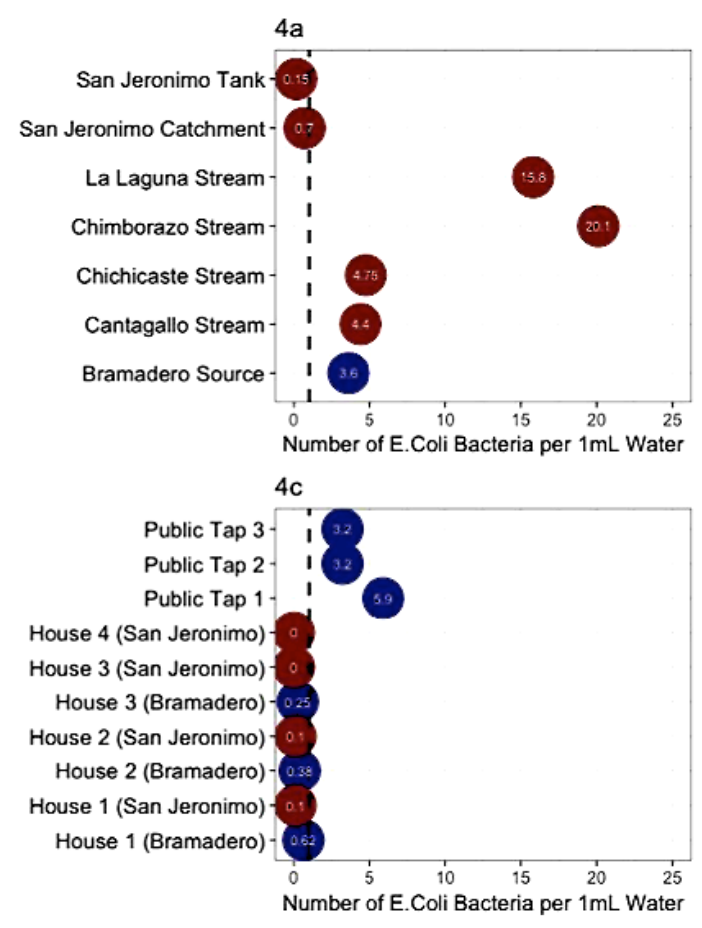
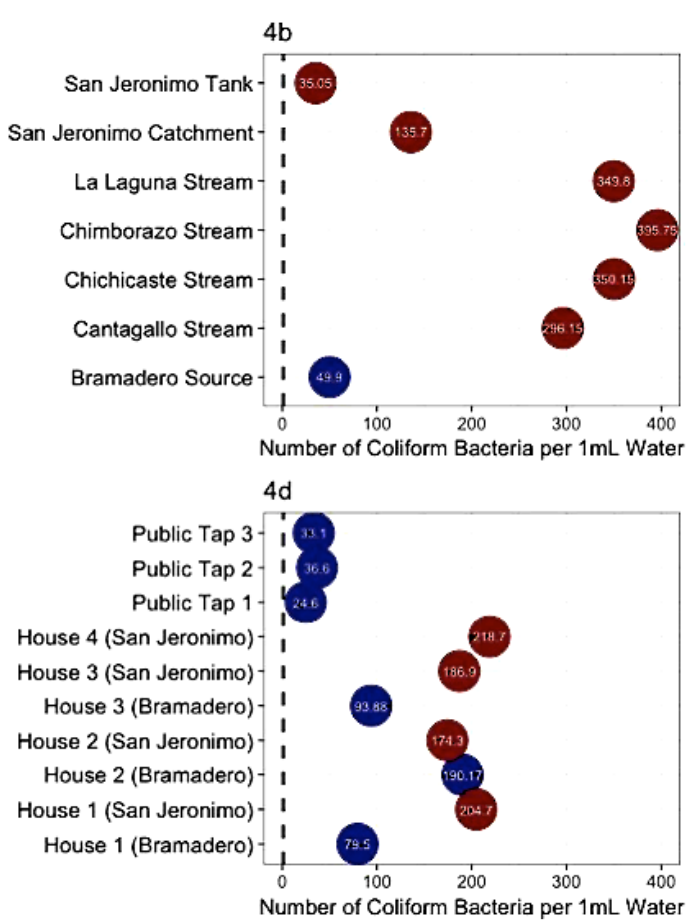

Across both communities, focus group discussions also highlighted that many people suffered a lack of hope in the "do nothing/suffer through it" response, a finding corroborated by survey data from SJ, and one which speaks to embodied experiences of lean food and water months.

The frequency of water insecurity coping responses (Table 2B) also helps to compare the experiences of drought impacts in SJ vs. B. For instance, in B, more people overall adopted the most severe coping responses to fulfill critical household needs (e.g., using less preferred water sources, arguing with a neighbor about water access). In an interview, a community leader in B partly attributed the reliance on alternative water sources to problems in the aging infrastructure of the village water system. In contrast, nearly all people in $\mathrm{SJ}$ reported washing with less water in response to drought, though people in B reported a higher number of lean bathing months. This highlights that even when people in SJ do not lose full access to water for bathing or cooking, they nonetheless experience drought as a deterioration in terms of their access to sufficient water (or water of sufficient quality; Fig. 5).

Our analysis of focus group discussions and interviews build on these understandings by indicating several qualitative differences in how men and women experience limited access to food and water. In a July 2017 focus group, for instance, men and women were asked to discuss coping responses to water insecurity. One woman responded,
In times when they cut the water, we have to cut back on household necessities. One would like to plant something [in the home garden], but there is not enough water. If I need to wash clothes, maybe I'll wait a few days, and leave some water in reserve for cooking, but there are some things for which I cannot wait. So more than anything, there are worries.

These concerns were also raised with reference to gendered distinctions in household labor. For example, when talking about worries surrounding sufficient water for dishwashing and cooking in a focus group, female participants raised eyebrows about men expressing concerns about water for cooking, asking, "When was the last time you guys cooked?"

Participant observation and a series of focus groups conducted with smallholders in the study area to develop gendered agricultural calendars suggest that many household, farm, and community tasks are done by both men and women (e.g., weeding, planting, and harvesting); other activities such as spraying crops (both organic and synthetic pesticides), plowing, and repairing broken water pipes are more frequently reported as men's work. Gendered agricultural roles often reported as women's work include caring for home gardens, coffee nursery planting, as well as a wide range of frequently undervalued household work, including cooking, cleaning, and caring for children. These 
Table 2. Numbers and proportions of respondents using specific coping responses to food and water insecurity, disaggregated by community and sex. $N=78$. Source: Sex-disaggregated survey; coping severity scores from focus groups.

\begin{tabular}{|c|c|c|c|c|c|}
\hline \multirow[b]{2}{*}{ Coping response } & \multicolumn{2}{|c|}{ San Jeronimo } & \multicolumn{2}{|c|}{ Bramadero } & \multirow[b]{2}{*}{ Coping severity score } \\
\hline & Female & Male & Female & Male & \\
\hline \multicolumn{6}{|l|}{ (A) Food insecurity coping responses } \\
\hline Do nothing (suffer through it) & $4(21 \%)$ & $2(10 \%)$ & $0(0 \%)$ & $1(5 \%)$ & 4.0 \\
\hline Sell assets (e.g., cattle, land) & $0(0 \%)$ & $0(0 \%)$ & $0(0 \%)$ & $0(0 \%)$ & 4.0 \\
\hline Sell future crop at low price & $0(0 \%)$ & $0(0 \%)$ & $0(0 \%)$ & $0(0 \%)$ & 3.6 \\
\hline Seek off-farm labor & $4(21 \%)$ & $2(10 \%)$ & $2(11 \%)$ & $1(5 \%)$ & 2.8 \\
\hline Spend savings & $10(53 \%)$ & $17(81 \%)$ & $2(11 \%)$ & $5(26 \%)$ & 2.6 \\
\hline Credit, loans, or nongovernmental organization assistance & $1(5 \%)$ & $0(0 \%)$ & $0(0 \%)$ & $0(0 \%)$ & 2.2 \\
\hline Reduce household expenditures & $1(5 \%)$ & $5(24 \%)$ & $0(0 \%)$ & $1(5 \%)$ & 1.4 \\
\hline Increase harvest of wild foods (non-forest) & $4(21 \%)$ & $9(43 \%)$ & $2(11 \%)$ & $1(5 \%)$ & 1.4 \\
\hline Increase farm harvest & $2(11 \%)$ & $1(5 \%)$ & $1(5 \%)$ & $0(0 \%)$ & 1.4 \\
\hline Seek help from family or friends & $2(11 \%)$ & $4(19 \%)$ & $13(68 \%)$ & $11(58 \%)$ & 1.4 \\
\hline Harvest more wild foods from forests & $0(0 \%)$ & $1(5 \%)$ & $1(5 \%)$ & $2(11 \%)$ & 1.2 \\
\hline \multicolumn{6}{|l|}{ (B) Water insecurity coping responses } \\
\hline Wash with less water & $19(100 \%)$ & $19(90 \%)$ & $8(42 \%)$ & $10(53 \%)$ & 2.0 \\
\hline Wash clothing less frequently & $9(47 \%)$ & $7(33 \%)$ & $5(26 \%)$ & $7(37 \%)$ & 2.0 \\
\hline Cook with less water & $0(0 \%)$ & $1(5 \%)$ & $3(16 \%)$ & $2(11 \%)$ & 2.0 \\
\hline Ask to borrow water & $1(5 \%)$ & $2(10 \%)$ & $2(10 \%)$ & $2(11 \%)$ & 4.0 \\
\hline Argue with community member about water usage & $1(5 \%)$ & $2(10 \%)$ & $0(0 \%)$ & $2(10 \%)$ & 4.0 \\
\hline Use less preferable water source & $0(0 \%)$ & $0(0 \%)$ & $3(16 \%)$ & $2(11 \%)$ & 4.0 \\
\hline Bathe less frequently & $1(5 \%)$ & $0(0 \%)$ & $0(0 \%)$ & $2(11 \%)$ & 2.0 \\
\hline Do not bathe [for multiple days] & $0(0 \%)$ & $0(0 \%)$ & $0(0 \%)$ & $3(16 \%)$ & 2.0 \\
\hline Go to bed thirsty & $1(5 \%)$ & $0(0 \%)$ & $1(5 \%)$ & $1(5 \%)$ & 3.0 \\
\hline Use water without permission & $1(5 \%)$ & $2(10 \%)$ & $0(0 \%)$ & $0(0 \%)$ & 4.0 \\
\hline Go entire day without drinking & $0(0 \%)$ & $1(5 \%)$ & $0(0 \%)$ & $1(5 \%)$ & 3.0 \\
\hline Argue with family member about water usage & $1(5 \%)$ & $0(0 \%)$ & $0(0 \%)$ & $0(0 \%)$ & 4.0 \\
\hline Do not wash food & $0(0 \%)$ & $0(0 \%)$ & $0(0 \%)$ & $1(5 \%)$ & 4.0 \\
\hline
\end{tabular}

gendered roles likely influence perceptions of water-scarce months for cooking and cleaning, as the women's responsibilities are more likely to lead to accurate perceptions. However, we did not try to calibrate the lean month measure among women's groups or between women and men. Participant observation shows that exceptions to these gendered norms are common, and we have visited households in the study area in which men are cooking and serving food. Through their own initiative as well as through co-op led programs, women also produce and sell their own coffee, honey, or other products. Rural household structures led by a single woman doing all key tasks are also relatively common, although less so in our sample. Such norms and the occasional fluidity of gender roles and responsibilities speak to the limits of a sex-disaggregated survey that was not necessarily gender-sensitive (e.g., reflecting differences within households of power, the norms mediating gendered division of labor, and other relational dimensions of gender).

Our within-village analysis of men's and women's experiences of food and water security and participation in resource governance will benefit from a consideration of how wealth and agricultural asset ownership intersect with traditionally defined gender roles and responsibilities. A suggestive finding shows that only 8 women vs. 18 men reported owning the milpa plots, with another 2 plots owned by both men and women or a child, and the rest unreported. Gendered divisions of labor surrounding water collection reveal that women also bear disproportionate responsibility for fetching water and finding replacement sources when access is lost or threatened. In times of scarcity, several female respondents reported walking to other communities, and others bathe in streams instead of their houses or ask neighbors with private wells or storage tanks for access.

A brief intersectional analysis considering income differences contributes to explaining some of the variation in Table 1 (e.g., large standard deviations) and sets the context for the following discussions of governance. Analysis of total gross annual income reported in the surveys shows that men reported earning nearly double the amount that women reported, and there was considerable variation among women in both communities (women reported a minimum of less than USD \$20 and a maximum of $\$ 2275$, whereas males reported a minimum of $\$ 114$ and a maximum of \$6500). Further analysis found that individuals in the top income quintile averaged approximately 0.5 and 0.4 fewer lean food months in B and SJ, respectively, than those in the bottom quintile. A recent study, which sampled $>300$ farmers in the broader study area, found statistically significant patterns correlating income and landholdings to both food and water lean months (Bacon et al. 2021). Participant observation and interviews also suggest several ways that income (and wealth) variation help explain who holds what positions in local governance committees. For example, a female coordinator of B's water committee convenes regular meetings, negotiates resources with nongovernmental organizations, and helps lead resistance efforts to upstream diversions. She also has piped water and a back-up well in her house and reports more water security and greater food security compared to others in her community. In focus groups and meetings, it is evident that many of the other women in B prefer that she speaks first and more often. While these variations influence governance and who is likely to be 
elected president of the CAPS or the cooperative, they are relatively small compared to the significant socioeconomic power wielded by a large commercial grower that recently purchased land and diverted water upstream from $\mathrm{B}$.

\section{Conflict across scales, water contamination, and gendered impacts downstream}

To shed further ethnographic light on the ways that institutions and gender relations structure food and water access, we draws on participation observation, focus groups, and interviews to summarize and analyze a salient natural resource conflict that emerged repeatedly as a theme in interviews and focus group discussions. In addition to influencing experiences of food and water security in the study communities, we also present this case to explain the limitations that local institutions face as they struggle to secure food and water access in the study area.

The Bramadero stream starts in $\mathrm{V}$ and is a primary source of water for B and other downstream communities (Fig. 1). V, like $\mathrm{SJ}$, is a mountaintop farming community in which ex-combatants organized a smallholder cooperative and accessed land through the 1980s agrarian reform. Unlike the SJ co-op, the V co-op has sold user rights for its collective land title to large-scale commercial producers and has permitted logging since 2010. Downstream stakeholders repeatedly expressed concerns about deforestation, agrochemical contamination, and irrigation demands associated with these transactions, particularly the sale of $>35$ ha of prime agricultural land with key water sources to a large-scale potato grower (papero). According to interviews, the papero deforested the upper watershed and dammed the Bramadero stream to enable irrigation.

The papero operation represents one of an increasing number of stream diversions for cash crop irrigation. According to local agency development agency staff, most of these operations are facilitated by male farmers using simple rubber tubing or gas powered pumps to channel water to fields. In conversations with the leader of B's water committee, we also learned that male residents frequently use the Bramadero stream to water livestock and wash backpack agrochemical sprayers, contributing to lower flows and contamination downstream. This development disproportionately affects women, who often wash clothes and bathe in streams. Downstream contamination was so prevalent in B that rashes were reported after washing clothes or bathing, especially during the dry season months. In response to skin rashes, mothers established a community norm that the clothes of babies under three years old could not be washed in the stream.

Residents of B, SJ, and other neighboring communities have protested these developments, denouncing the deforestation, water diversions, and pollution associated with intensive potato production, and taking their complaints to district-level environmental and municipal government authorities. However, residents claim that although the grower removes the dam after officials visit, he rebuilds it three days later. Several residents have filed a legal complaint based on Law 722's prohibition of water privatization. Downstream residents are also organizing stream cleanup days, with up to $50 \%$ of nearby community members participating, and by covertly cutting upstream irrigation lines. One female community leader in B also talked about secretly sending local residents upstream to document contamination and count "illegal" in-stream irrigation pumps.
This conflict provides a point of entry for exploring how gendered relationships and biophysical environments are co-produced and changed over time (Nightingale 2020). A walk upstream in the creek from $\mathrm{B}$ revealed the combination of irrigation hoses and pipes placed into the stream to support male-dominated farming activities (Fig. 6A) despite community rules to prohibit pumped water withdrawals, especially during drought. We also saw an example of gendered co-production in which female residents arranged stones in a streambed to wash clothes (Fig. 6B). In turn, the downstream streambed environment intersects with gendered divisions of labor, as male-dominated irrigation and agrochemical use influence downstream stream flow and chemical concentrations in downstream locations where women congregate for their labor, which necessitates bodily exposure. Additional evidence illustrates the large quantity of agrochemical waste containers collected in the study area (Fig. 6C) and the conditions at an improved village water system source (Fig. 6D). Although we do not have systematic data on irrigation in the study area or on the effects of these developments on local hydrological conditions, participant observation suggests that spraying herbicides and insecticides has continued and that men are more likely to apply the pesticides than women.

Although organic coffee production is common in the area, survey data and participant observation suggest considerable agrochemical use in other production areas, sometimes by the same producer. Furthermore, focus group respondents and local experts also expressed concern about widespread agrochemical use and contamination in local streams. The threat posed by this contamination is revealed by the collective action of $>70$ residents representing water committees and co-ops in the Cantagallo mountain area during a July 2019 workshop. One short-term collective action that emerged from this workshop was a request for ASDENIC to help coordinate an empty pesticide container clean-up campaign. Residents collected more than four $>90 \mathrm{~kg}$ bags of empty containers, which were returned to the industry for proper disposal during a subsequent campaign (Fig. 6C).

\section{DISCUSSION}

Several influential publications have called for an integrated assessment of food and water security at the household and individual scales (Wutich and Brewis 2014, Jepson et al. 2017), and a recent publication has done that, with a focus on coping responses (Young et al. 2021). However, to the best of our knowledge, ours is one of the first empirical studies to measure lean food and lean water months simultaneously. We used a fourpillar framework of availability, access, use, and stability to assess individual food and water security while relying on approaches from FPE to analyze drought impacts across scales, institutions, and gender. Within the four-pillar framework, much of our analysis focuses on the terms, qualities, and temporality of access to food and water.

In response to our first research question, and consistent with our hypothesis, survey and focus group data suggest that the experiences of food and water security were as intense during the 2014-2016 drought as during previous extreme events and as measured by comparative coping stress scores. The drought correlated with a greater proportion of smallholders reporting lean food months than has been recorded in neighboring villages and throughout Mesoamerica in non-drought times (Caswell et al. 2012), along with challenges accessing sufficiently high-quality food and water. These results indicate that 
Fig. 6. Photographs of constructed landscape features in the case study communities. (A, top left) Irrigation hoses inserted upstream of Bramadero. Credit: Lisa Kelley. (B, top right) A stream bed modified with rocks used for washing clothes. Credit: Christopher Bacon. (C, bottom left) Bag full of agrochemical bottles from a cleanup campaign. Credit: Raul Diaz, ASDENIC. (D, bottom right) New village water system storage tank in a coffee field near San Jeronimo. Credit: Raul Diaz, ASDENIC.
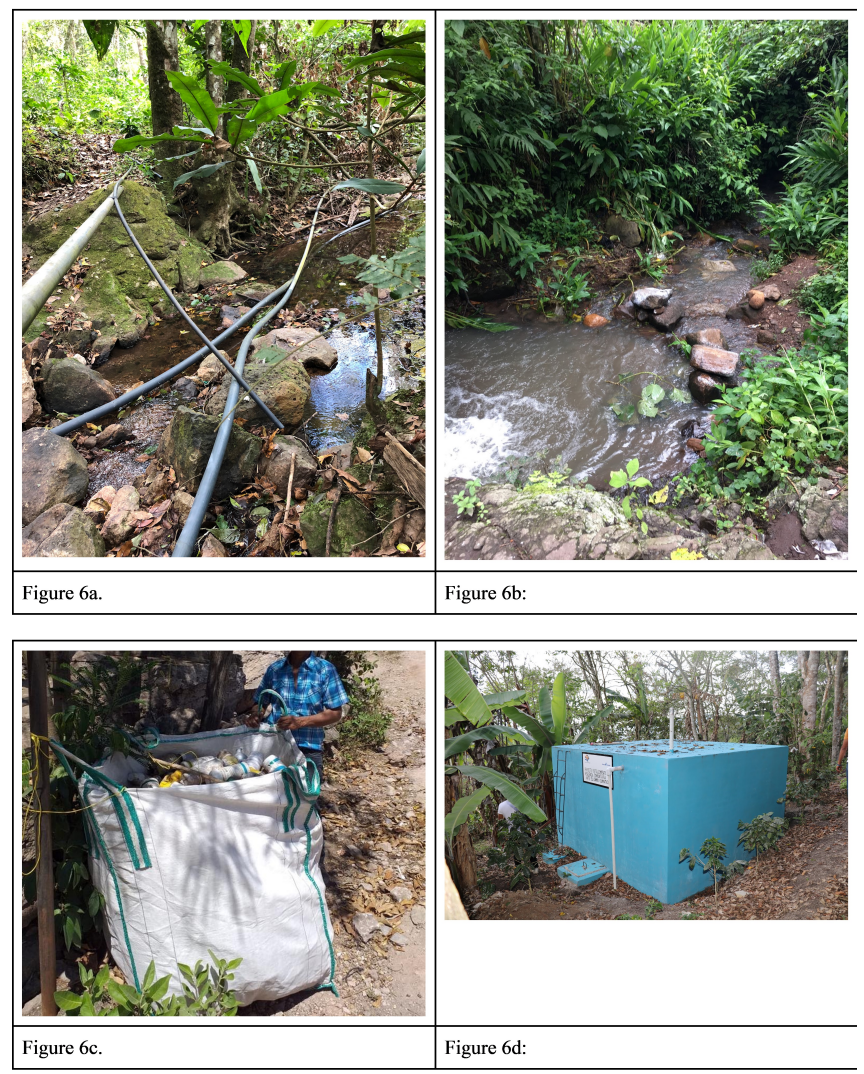

food and water access dynamics are influenced (though not determined) by interannual climate events and other shocks (FAO et al. 2019).

Our definitions of food and water security and measures of lean food and water months also revealed important temporal dimensions of smallholder food and water access challenges. Specifically, by expanding our analysis from the well-documented food insecure months (Méndez et al. 2010, Morris et al. 2013, Bacon et al. 2017) to include lean water months, we see that the water insecure months (Jan-May or March-May) combined with the food insecure months (June-July or June-August) amount to a combined period of 4.5 or 6.5 lean months on average in SJ and $\mathrm{B}$, respectively. Recent work replicating an analysis of the matched food and water lean month indicators developed here suggests the applicability of these findings throughout northern Nicaragua (Bacon et al. 2021) and the validity of these lean month indicators and findings despite sample size limits. Future studies analyzing smallholder systems in different contexts could complement such approaches with other indicators for assessing food and water quality beyond the dietary diversity and bacterial water contamination metrics employed here. Additional studies could further strengthen our four-pillar approach to both food and water security by developing methods for assessing the use dimensions and the relative severity of coping responses (e.g., reliance on secondary water sources or use of less preferred foods).

Our data suggest that the biophysical conditions, power relations, gender, and institutions contribute to shaping food and water access, but without more data, we cannot identify the relative influence of each factor. For instance, the community of B generally receives less precipitation and has less water availability than $\mathrm{SJ}$; it has one stream, in which both water quantity and quality are impacted from upstream, vs. four streams in SJ. However, the upstream commercial grower's water diversions from B's stream undermines downstream water access in ways that may have prompted greater impacts than the biophysical limits to water availability. Similarly, findings suggest that B, the community with weaker local institutions, experienced the longer duration of water stress, whereas SJ, the community with stronger co-operative organization and greater access to regional institutions, may have experienced higher food stress (see Fig. 4, Tables 1 and 2). Two limitations to this finding were the small sample size and the role of asset sales in driving the higher coping score severity in SJ, a finding that may indicate that people in SJ simply had more assets to liquidate than did people in B. Similarly with respect to gender, the slightly higher proportion of men than women in B and SJ reporting lean food and water months (Figs. 4A,B and 4C,D, respectively) could be influenced by the greater time men report spending in milpas; men's stronger role in early crop development may lead them to worry about crop failures after planting in June or in August, shaping their understanding of water insufficiencies.

Nonetheless, the largest difference in lean water months is not between gender, but between communities, and our work suggests several possible explanations for this finding. One contributing factor to lower lean water months in SJ than B could be that the local institutions in SJ have secured improvements to water access and quality (e.g., when the co-op and CAPS in SJ installed a new drinking water system and found new feeder streams during the dry season). In contrast, the apparent limitation of the stronger institution in SJ in addressing food insecurity may reflect the greater importance of individualized (vs. collective) actions in securing food vs. water entitlements (Devereux 2001), particularly given evidence that food insecurity is closely mediated by global and regional markets (Bacon et al. 2021). Other possible explanations include the SJ farmers' higher dependency on coffee, which leaves them more vulnerable to coffee rust than those in B, and the climatic evidence (Fig. 3), which suggests a slightly more severe drought in SJ but generally drier conditions and less water availability in $\mathrm{B}$.

Although our quantitative analysis of survey results shows that gender was not a significant predictor of most individual indicators of food and water insecurity, our qualitative analysis of the downstream conflict revealed important gendered inequalities and injustices. This water conflict case indicates to us that women disproportionately faced chemical exposures in the 
water in ways connected to qualitative findings surrounding gendered divisions of household labor. Women are more likely to provide food and water for the households and rely on surface water for multiple domestic uses. We found that these aspects work alongside upstream developments in the study area to shape the uneven terms of access to high-quality water and the uneven distribution of environmental burdens along gendered lines.

Though we anticipated that gender relations would play a significant role in explaining quantified food and water insecurity outcomes reported in the sex-disaggregated survey, we found fewer differences than expected. This result could relate to study limitations in sample size or survey design. However, our finding also resonates with a recent FPE mixed-methods study assessing gender-differentiated access, use, knowledge, governance, and experiences of water across communities in South Africa and Ghana (Harris et al. 2017). Harris et al. (2017) surveyed 478 households, and their statistical analysis revealed several significant differences in male vs. female responses. The authors note, "the gender differences were certainly much less consistent, and less pronounced, than expected" (Harris et al. 2017:571). Their further analysis identifies the limits of reducing a gendered analysis to a male-female binary and shows the importance of an intersectional analysis. Although our study could be extended with further research to address intersectionality (see also Elmhirst 2015, Sultana 2021), we follow the three previous studies in highlighting the importance of qualitative analysis of governance across scales because it helped to reveal other differences, as well as conflict and changing gender relations. These findings illuminate the value of the FPE framework and mixed-methods field research in helping to explain the multiple dynamics shaping the terms of household food and water access.

Overall, a combined FPE and community-based participatory action research approach also helped us to reflect on what might be done to improve the terms of food and water access. Taken together, these approaches offer concepts that recognize human agency and pose strategies for co-production of knowledge and change (Sundberg 2017). For example, after we shared the $E$. coli water contamination findings, CAPS convened community assemblies and shared results more widely, and residents intensified management activities, with more frequent systemwide cleaning and chlorine flushes. In recent years, CAPS and allied nongovernmental organizations beyond our study region have also organized a national network to share best practices and advocate for government support (Romano 2019). In addition, Nicaragua's smallholder cooperatives have organized national and international federations to represent their politicoeconomic interests to national and international agencies and further professionalize their staff (Bacon et al. 2017).

\section{Expanded discussion and future research}

Persistent challenges in developing holistic explanations of how individual and household food and water security relate to gender and institutions (and intersect with broader constraints and opportunities associated with politico-economic and agroenvironmental changes) suggest several productive avenues for future research. We next identify several additional questions emerging from our study and suggest future research topics. Our goal is to contribute to a broader action-oriented research agenda rooted in a FPE of the gendered and institutional dimensions of agrarian change (Ribot and Peluso 2003, Agrawal 2010, Nightingale 2020) in relation to food and water access across scales (Brewis et al. 2020, Wutich 2020).

While the complexity of the topic and the availability of evidence from our study suggest considerable uncertainty in assessing the contours and consequences of the watershed conflict described above, we offer several hypothesized causative relationships grounded in our ethnographic research and relevant literature. Specifically, although gender and institutions intersect in multiple ways with irrigation, chemical contamination, and upstream commercial agricultural expansion, we suggest that this conflict primarily speaks to how the gendered divisions of labor and power inequalities influence exposure to harm and shape water and food injustices (Alston and Akhter 2016). This idea is evidenced by the way that the wealthy male potato farmer executed upstream water diversions for irrigation, affecting both male and female members of downstream communities. It is also evidenced by information from participant observation and focus group discussions that suggest male farmers are more likely than women to apply pesticides in these and other northern Nicaraguan communities. Such individuals transgress community norms by washing agrochemical equipment in the same streams that are primarily used by women for bathing, washing clothes, and sometimes to fetch water for cooking. Inequalities in asset ownership also likely intersected with these gendered divisions of reproductive and productive labor to shape inequalities in access to available coping responses. Although all connected households must contend with frequent village drinking water system failures (for instance, reports of 7-14 days without water in the pipes were common), those without access to alternative water sources such as home wells are at greater risk of exacerbating their babies' exposure to contaminated stream water because it is the only back-up water source for washing and cooking when water systems or deliveries fail.

Although our data cannot conclusively resolve these questions, power inequalities and cross-scalar conflicts (both upstream or downstream and regarding access to enforcement from government institutions) also appear to have structured the higher levels of water insecurity reported in B. Communities are responding to this challenge by organizing at watershed scales. Recently, the CAPS in B and SJ and the co-op in SJ have united to register complaints to government officials and civil society organizations against V's larger commercial plantations and its agricultural co-op, which holds a collective land title. Future work can build from our analysis to explain not only the norms and politics of recognition structuring women's efforts to govern and physically alter streams for their use, but also how these alterations and collective actions shape local hydrologies. Such work has the potential to go further in addressing questions surrounding the co-construction of gender relations, social difference, and environmental change than we were able to here.

Despite the fact that Nicaragua's Law 722 establishes the right to water and prohibits privatization, thus far, downstream residents have not been able to stop deforestation or prevent significant upstream stream flow diversions for irrigated agriculture. Some residents of B have resorted to classic "weapons of the weak" (Scott 1998), including clandestine monitoring of stream flow diversions and cutting of irrigation pipes. Drought, upstream 
water diversions, accumulated downstream contamination, and power inequities further influence this conflict. Participant observation of hundreds of meters of plastic irrigation pipe in SJ to be used for small-scale irrigation of new coffee nurseries and other crops, as well as conversations with local non-profit agency leaders, reveal that several international development agencies are promoting irrigation to address drought and climate change. However, they are doing so without an adequate study of stream flows, sources of chemical contamination in streams, downstream risks, or cross-scale watershed governance. This lack of study suggests that their efforts to promote a resilient response to the coffee rust and drought may inadvertently exacerbate existing gendered environmental injustices and vulnerabilities faced by some community members; these are important themes for future research.

Historical considerations indicate the importance of several factors that influence women's power, political participation, and asset ownership, including: women's social movements, several policy changes in the $1980 \mathrm{~s}$, the persistent power of Neoliberalism, and the uneven and sometimes contradictory efforts of civil society (Babb 2001). Although several changes have contributed to gains in women's access to land and increased prominence in the leadership roles in both nongovernmental and governmental organizations, a study of women's land ownership and intra-household violence in Nicaragua revealed a relatively small proportion of women landowners, which may "reflect the reality that social constructions of gender, combined with cultural practices of restricting women's access to land, have prohibited women from realizing their legal rights"(Grabe 2010:153). Along these lines, Neumann's (2013) ethnographic study in rural Nicaragua assessed the rise in development efforts that prioritize women and found that although material gains occurred in some cases, the programs increased women's daily workload, contributing to a gendered burden of development. She also found that by "exploiting women's unpaid community care labor, these NGO [nongovernmental organization] and state-led programs entrench established gender roles and responsibilities" (Neumann 2013:1). Both Grabe's (2010) and Neumann's (2013) studies suggest using caution in efforts to address the persistent and often gendered food and water insecurities found in our study through overly simplistic women's economic empowerment projects. They also suggest the need for future research and action addressing the political, economic, and ideological belief systems that perpetuate gender inequality, and how they can be changed.

\section{CONCLUSIONS}

We aimed to contribute to the methods and indicators for integrating studies of food and water security, and to link theory and field research with an analysis of local institutions and gender within an FPE framework. Our analysis of gendered inequalities in the water access conflict in the study communities during a drought suggests a generalized hypothesis about cumulative food and water access and quality challenges. We predict that as climate change accelerates and larger scale commercial agriculture expands, the challenges of accessing water and food in smallholder farming communities will expand, conflicts will become more common, and more environmental injustices will accumulate in downstream communities and bodies. Similar cases of politico-economic forces influencing patterns of local scarcity are unfortunately common and could be investigated as small- scale land and water grabs (Borras et al. 2012). For example, a study in Nicaragua's Pacific coast found that large-scale tourism development diverted groundwater from residents and sparked conflict, and concluded that weak enforcement of progressive water laws and the lack of investment undermined local drinking water quality and access (LaVanchy et al. 2017). The extent to which local institutions such as cooperatives or village water communities can mediate local climate stressors, community dynamics, landscapes, and broader political economic forces, as well as more equally distribute existing resources, restore landscapes, and improve access to healthy food and water, will largely depend on work that improves gender equity, promotes women's leadership, and fosters inclusive collective action.

The FPE approach also suggests using future studies to analyze potential limits as these grassroots networks attempt to scale up promising strategies (e.g., increasing women's voice in governance decisions, and their expanding roles in cooperatives; see Lyon et al. 2017) into regional, national, and global institutions dominated by neoliberal logic (Dupuits 2019). The possibility of stronger community and women's voices in resource governance could influence local power relations, affecting which farmers secure water access (Damonte 2019), and could open new spaces for how smallholders can manage their farms (Zimmerer et al. 2019), make their livelihoods, and creatively struggle to sustain access to food and water.

Responses to this article can be read online at: https://www.ecologyandsociety.org/issues/responses. $\mathrm{php} / 12716$

\section{Acknowledgments:}

We thank William Sundstrom for feedback on this manuscript; Raul Diaz, William Sundstrom, and Ed Maurer for collaboration on this project; and Raul Diaz, Santiago Butanco, and five dynamic Nicaraguan community leaders for their contributions to field research. We are grateful to the farmers, residents, cooperatives, and water committees in these communities for sharing their time and ideas. We are also grateful for the thoughtful comments offered by two peer reviewers and the journal's editorial team. Special thanks go to student research assistance from Santa Clara University students, including Claire Smoker, Lauren Cloward, Kimberly Grandi Soriano, Gabbi Ballardo, Kylie Griggs, and Ava Gleicher. This work was supported by the National Science Foundation (BCS 1539795); Santa Clara University's College of Arts and Sciences, Dean, Provost, Center for Food Innovation \& Entrepreneurship, and Center for Arts and Humanities; and the Ignatian Center for Jesuit Education's Bannan Institute. Complementary funding from the Project Assessment of Diversification Strategies in Smallholder Coffee Systems (AF 1507-086: FDNC Engt 00063479) was supported under the Thought for Food Initiative of the Agropolis Foundation (through the Investissements d'avenir programme with reference number ANR10-LABX-0001-01"), Fondazione Cariplo and Daniel and Nina Carasso Foundation. Additional support was provided by National Science Foundation grant BCS 2117976. The projects and study designs were approved by Santa Clara 
University's Institutional Review Board, with the protocol for the first part of the study approved on 24 June 2013, and the protocol for the second part approved on 17 June 2015.

\section{Data Availability:}

The data and code that support the findings of this study may be available in anonymized format from the corresponding author, $C B$. The datalcode are not publicly available because some contain potentially identifiably information that could compromise the privacy of research participants. The precipitation data are in the public domain.

\section{LITERATURE CITED}

Adams, E. A., L. Juran, and I. Ajibade. 2018. 'Spaces of exclusion' in community water governance: a feminist political ecology of gender and participation in Malawi's urban water user associations. Geoforum 95:133-142. https://doi.org/10.1016/j. geoforum.2018.06.016

Agrawal, A. 2010. Lcal institutions and adaptation to climate change. Pages 173-178 in R. Mearns and A. Norton, editors. Social dimensions of climate change: equity and vulnerability in a warming world. World Bank, Washington, D.C., USA.

Alaniz, B. 2021. Proyecto tecnología para la gestión sostenible del recurso hídrico: estrategia para la equidad de género y plan de implementación. SIMAS, Managua, Nicaragua. [online] URL: https://caps-nicaragua.org/media/adjuntos/Estrategia_de_g\% C3\%A9nero CAPS 1 compressed.pdf

Alston, M., and B. Akhter. 2016. Gender and food security in Bangladesh: the impact of climate change. Gender, Place and Culture 23(10):1450-1464. https://doi.org/10.1080/0966369X.2016.1204997

Anderzén, J., A. G. Luna, D. V. Luna-González, S. C. Merrill, M. Caswell, V. E. Méndez, R. H. Jonapá, and M. M. T. G. Cacho. 2020. Effects of on-farm diversification strategies on smallholder coffee farmer food security and income sufficiency in Chiapas, Mexico. Journal of Rural Studies 77:33-46. https://doi. org/10.1016/j.jrurstud.2020.04.001

Babb, F. E. 2001. After revolution: mapping gender and cultural politics in neoliberal Nicaragua. University of Texas Press, Austin, Texas, USA.

Bacon, C. M. 2015. Food sovereignty, food security and fair trade: the case of an influential Nicaraguan smallholder cooperative. Third World Quarterly 36(3):469-488. https://doi. org/10.1080/01436597.2015.1002991

Bacon, C. M., W. A. Sundstrom, I. T. Stewart, and D. Beezer. 2017. Vulnerability to cumulative hazards: coping with the coffee leaf rust outbreak, drought, and food insecurity in Nicaragua. World Development 93:136-152. https://doi.org/10.1016/j. $\underline{\text { worlddev.2016.12.025 }}$

Bacon, C. M., W. A. Sundstrom, I. T. Stewart, E. Maurer, and L. C. Kelley. 2021. Towards smallholder food and water security: climate variability in the context of multiple livelihood hazards in Nicaragua. World Development 143:105468. https://doi. org/10.1016/j.worlddev.2021.105468
Bee, B. A. 2016. Power, perception, and adaptation: exploring gender and social-environmental risk perception in northern Guanajuato, Mexico. Geoforum 69:71-80. https://doi.org/10.1016/ j.geoforum.2015.12.006

Bezner Kerr, R. 2014. Lost and found crops: agrobiodiversity, indigenous knowledge, and a feminist political ecology of sorghum and finger millet in northern Malawi. Annals of the Association of American Geographers 104(3):577-593. https:// doi.org/10.1080/00045608.2014.892346

Borras, S. M. Jr., J. C. Franco, S. Gómez, C. Kay, and M. Spoor. 2012. Land grabbing in Latin America and the Caribbean. Journal of Peasant Studies 39(3-4):845-872. https://doi.org/10.1080/030$\underline{66150.2012 .679931}$

Brewis, A. A., B. Piperata, A. L. Thompson, and A. Wutich. 2020. Localizing resource insecurities: a biocultural perspective on water and wellbeing. Wiley Interdisciplinary Reviews: Water 7(4): e1440. https://doi.org/10.1002/wat2.1440

Burandt, A., and T. Mölders. 2017. Nature-gender relations within a social-ecological perspective on European multifunctional agriculture: the case of agrobiodiversity. Agriculture and Human Values 34(4):955-967. https://doi.org/10.1007/s10460-016-9763-7

Carney, J. 1993 Converting the wetlands, engendering the environment: the intersection of gender with agrarian change in the Gambia. Economic Geography 69(4):329-348. https://doi. org/10.2307/143593

Caswell, M., V. E. Méndez, and C. M. Bacon. 2012. Food security and smallholder coffee production: current issues and future directions. Agroecology and Rural Livelihoods Group Policy Brief 1. University of Vermont, Burlington, Vermont, USA. [online] URL: https://scholarcommons.scu.edu/ess/2/

Chevalier, J. M., and D. J. Buckles. 2019. Participatory action research: theory and methods for engaged inquiry. Routledge, London, UK. https://doi.org/10.4324/9781351033268

Cleaver, F., and K. Hamada. 2010. 'Good' water governance and gender equity: a troubled relationship. Gender and Development 18(1):27-41. https://doi.org/10.1080/13552071003599996

Cook, C., and K. Bakker. 2012. Water security: debating an emerging paradigm. Global Environmental Change 22(1):94-102. https://doi.org/10.1016/j.gloenvcha.2011.10.011

Damonte, G. H. 2019. The constitution of hydrosocial power: agribusiness and water scarcity in Ica, Peru. Ecology and Society 24(2):21. https://doi.org/10.5751/ES-10873-240221

Deere, C. D., G. E. Alvarado, and J. Twyman. 2012. Gender inequality in asset ownership in Latin America: female owners vs household heads. Development and Change 43(2):505-530. https://doi.org/10.1111/j.1467-7660.2012.01764.x

Delgado-Serrano, M., J. Mistry, B. Matzdorf, and G. Leclerc. 2017. Community-based management of environmental challenges in Latin America and the Caribbean. Ecology and Society 22(1):4. https://doi.org/10.5751/ES-08924-220104

Devereux, S. 2001. Sen's entitlement approach: critiques and counter-critiques. Oxford Development Studies 29(3):245-263. https://doi.org/10.1080/13600810120088859 
Drèze, J., and A. Sen. 1991. Hunger and public action. Clarendon Press, Oxford, UK. https://doi.org/10.1093/0198283652.001.0001

Dupuits, E. 2019. Water community networks and the appropriation of neoliberal practices: social technology, depoliticization, and resistance. Ecology and Society 24(2):20. https://doi.org/10.5751/ES-10857-240220

Elmhirst, R. 2011. Introducing new feminist political ecologies. Geoforum 42(2):129-132. https://doi.org/10.1016/j.geoforum.2011.01.006

Elmhirst, R. 2015. Feminist political ecology. Pages 82-90 in A. Coles, L. Gray, and J. Momsen, editors. The Routledge handbook of gender and development. Routledge, London, UK.

Fehr, R., and W. G. Moseley. 2019. Gardening matters: a political ecology of female horticulturists, commercialization, water access, and food security in Botswana. African Geographical Review 38(1):67-80. https://doi.org/10.1080/19376812.2017.1286247

Food and Agriculture Organization (FAO), International Fund for Agricultural Development, United Nations Children's Fund, World Food Programme, and World Health Organization. 2019. The state of food security and nutrition in the world 2018: building climate resilience for food security and nutrition. Food and Agriculture Organization, Rome, Italy. [online] URL: https:// www.wfp.org/publications/2018-state-food-security-and-nutritionworld-sofi-report

Funk, C. C., P. J. Peterson, M. F. Landsfeld, D. H. Pedreros, J. P. Verdin, J. D. Rowland, B. E. Romero, G. J. Husak, J. C. Michaelsen, and A. P. Verdin. 2014. A quasi-global precipitation time series for drought monitoring. Data Series 832. United States Geological Survey, Reston, Virginia, USA. https://doi. org/10.3133/ds 832

Galiè, A., A. Mulema, M. A. M. Benard, S. N. Onzere, and K. E. Colverson. 2015. Exploring gender perceptions of resource ownership and their implications for food security among rural livestock owners in Tanzania, Ethiopia, and Nicaragua. Agriculture and Food Security 4:2. https://doi.org/10.1186/ s40066-015-0021-9

Garlick, C. 2015. CCAFS household baseline study, Latin America and South East Asia (2014-2015). V2. [data set] Harvard Dataverse, UNF:6:gQwCkRMdB1IUgJeaAJyhFA== [fileUNF]. https://doi.org/10.7910/DVN/PWVLTU

Godek, W., and M. A. García. 2018. Unpacking intra-household decision-making on smallholder farms in Colombia and Nicaragua to foster climate change adaptation. Unpublished report presented at Congress of the Latin American studies association, Barcelona, Spain, 23-26 May 2018. [online] URL: https://hdl.handle.net/10568/99830

Gonda, N. 2016. Climate change, "technology" and gender: "adapting women" to climate change with cooking stoves and water reservoirs. Gender, Technology and Development 20 (2):149-168. https://doi.org/10.1177/0971852416639786

Grabe, S. 2010. Promoting gender equality: the role of ideology, power, and control in the link between land ownership and violence in Nicaragua. Analysis of Social Issues and Public Policy 10(1):146-170.https://doi.org/10.1111/j.1530-2415.2010.01221.x
Hadley, C., and A. Wutich. 2009. Experience-based measures of food and water security: biocultural approaches to grounded measures of insecurity. Human Organization 68(4):451-460. https://doi.org/10.17730/humo.68.4.932w421317680w5x

Harris, L., D. Kleiber, J. Goldin, A. Darkwah, and C. Morinville. 2017. Intersections of gender and water: comparative approaches to everyday gendered negotiations of water access in underserved areas of Accra, Ghana and Cape Town, South Africa. Journal of Gender Studies 26(5):561-582. https://doi.org/10.1080/0958923$\underline{6.2016 .1150819}$

High Level Panel of Experts. 2017. Nutrition and food systems. A report by the high level panel of experts on food security and nutrition. HLPE Report 12. Committee on World Food Security, Rome, Italy. [online] URL: https://www.fao.org/3/i7846e/i7846e. pdf

International Forestry Resources and Institutions. 2013. International Forestry Resources and Institutions (IFRI) network: research methods. International Forestry Resources and Institutions, Hyderabad, India. [online] URL: http://ifri.forgov. org/resources/methods/

Isakson, S. R. 2009. No hay ganancia en la milpa: the agrarian question, food sovereignty, and the on-farm conservation of agrobiodiversity in the Guatemalan highlands. Journal of Peasant Studies 36(4):725-759. https://doi.org/10.1080/03066150903353876

Jepson, W. E., A. Wutich, S. M. Collins, G. O. Boateng, and S. L. Young. 2017. Progress in household water insecurity metrics: a cross-disciplinary approach. Wiley Interdisciplinary Reviews: Water 4(3):e1214. https://doi.org/10.1002/wat2.1214

Kelley, L. C., L. Pitcher, and C. Bacon. 2018. Using Google Earth engine to map complex shade-grown coffee landscapes in northern Nicaragua. Remote Sensing 10(6):952. https://doi. org/10.3390/rs10060952

Kennedy, G., T. Ballard, and M. C. Dop. 2011. Guidelines for measuring household and individual dietary diversity. Food and Agriculture Organization, Rome, Italy. [online] URL: https:// www.fao.org/publications/card/en/c/5aacbe39-068f-513bb17d-1d92959654ea/

Larson, A. M., and F. Soto. 2008. Decentralization of natural resource governance regimes. Annual Review of Environment and Resources 33:213-239. https://doi.org/10.1146/annurev. environ.33.020607.095522

LaVanchy, G. T., S. T. Romano, and M. J. Taylor. 2017. Challenges to water security along the "Emerald Coast": a political ecology of local water governance in Nicaragua. Water 9(9):655. https:// doi.org/10.3390/w9090655

Lyon, S., T. Mutersbaugh, and H. Worthen. 2017. The triple burden: the impact of time poverty on women's participation in coffee producer organizational governance in Mexico. Agriculture and Human Values 34:317-331. https://doi. org/10.1007/s10460-016-9716-1

Maurer, E. P., N. Roby, I. T. Stewart-Frey, and C. M. Bacon. 2017. Projected twenty-first-century changes in the Central American mid-summer drought using statistically downscaled climate projections. Regional Environmental Change 17:2421-2432. https://doi.org/10.1007/s10113-017-1177-6 
Maxwell, D., J. Coates, and B. Vaitla. 2013. How do different indicators of household food security compare? Empirical evidence from Tigray. Feinstein International Center, Tufts University, Medford, Massachusetts, USA. [online] URL: https:// www.alnap.org/system/files/content/resource/files/main/differentindicators-of-hfs.pdf

McKee, T. B., N. J. Doesken, and J. Kleist. 1993. The relationship of drought frequency and duration to time scales. Pages 179-184 in Proceedings of the Eighth Conference on Applied Climatology. American Meteorological Society, Boston, Massachusetts, USA.

Méndez, V. E., C. M. Bacon, M. Olson, S. Petchers, D. Herrador, C. Carranza, L. Trujillo, C. Guadarrama-Zugasti, A. Cordón, and A. Mendoza. 2010. Effects of Fair Trade and organic certifications on small-scale coffee farmer households in Central America and Mexico. Renewable Agriculture and Food Systems 25(3):236-251. https://doi.org/10.1017/S1742170510000268

Michelson, H., T. Reardon, and F. Perez. 2012. Small farmers and big retail: trade-offs of supplying supermarkets in Nicaragua. World Development 40(2):342-354. https://doi.org/10.1016/j. worlddev.2011.07.013

Morris, K. S., V. E. Mendez, and M. B. Olson. 2013. 'Los meses flacos': seasonal food insecurity in a Salvadoran organic coffee cooperative. Journal of Peasant Studies 40(2):423-446. https:// doi.org/10.1080/03066150.2013.777708

Mosley, L. M. 2015. Drought impacts on the water quality of freshwater systems; review and integration. Earth-Science Reviews 140:203-214. https://doi.org/10.1016/j.earscirev.2014.11.010

Neumann, P. J. 2013. The gendered burden of development in Nicaragua. Gender and Society 27(6):799-820. https://doi. org/10.1177/0891243213499447

Nguyen, T. T., A. Darnell, A. Weissman, E. A. Frongillo, R. Mathisen, K. Lapping, T. D. Mastro, and M. Withers. 2020. Social, economic, and political events affect gender equity in China, Nepal, and Nicaragua: a matched, interrupted time-series study. Global Health Action 13(1):1712147. https://doi. org/10.1080/16549716.2020.1712147

Nightingale, A. 2006. The nature of gender: work, gender, and environment. Environment and Planning D: Society and Space 24(2):165-185. https://doi.org/10.1068/d01k

Nightingale, A. J. 2011. Bounding difference: intersectionality and the material production of gender, caste, class and environment in Nepal. Geoforum 42(2):153-162. https://doi. org/10.1016/j.geoforum.2010.03.004

Nightingale, A. J. 2020. Environment and gender. In D. Richardson, N. Castree, M. F. Goodchild, A. Kobayashi, W. Liu, and R. A. Marston, editors. International Encyclopedia of Geography. Wiley, Hoboken, New Jersey, USA. https://doi. org/10.1002/9781118786352.wbieg0667.pub2

Niles, M. T., and M. E. Brown. 2017. A multi-country assessment of factors related to smallholder food security in varying rainfall conditions. Scientific Reports 7(1):16277. https://doi.org/10.1038/ s41598-017-16282-9
Nussbaum, M. C. 2011. Creating capabilities: the human development approach. Harvard University Press, Cambridge, Massachusetts, USA. https://doi.org/10.4159/harvard.9780674061200

Nyantakyi-Frimpong, H. 2017. Agricultural diversification and dietary diversity: a feminist political ecology of the everyday experiences of landless and smallholder households in northern Ghana. Geoforum 86:63-75. https://doi.org/10.1016/j.

geoforum.2017.09.003

Ostrom, E. 2005. Understanding institutional diversity. Princeton University Press, New Jersey, USA.

Pearson, A. L., M. C. Roberts, O. O. Soge, I. Ivanova, J. D. Mayer, and J. S. Meschke. 2008. Utility of EC 3M Petrifilm and sanitary surveys for source water assessment in Nyabushozi County, south-western Uganda. Water SA 34(2):279-284. [online] URL: https://journals.co.za/doi/pdf/10.10520/EJC116508

Pinstrup-Andersen, P. 2009. Food security: definition and measurement. Food Security 1:5-7. https://doi.org/10.1007/ s12571-008-0002-y

Poteete, A. R., M. A. Janssen, and E. Ostrom. 2010. Working together: collective action, the commons, and multiple methods in practice. Princeton University Press, Princeton, New Jersey, USA. https://doi.org/10.1515/9781400835157

Pretty, J., and H. Ward. 2001. Social capital and the environment. World Development 29(2):209-227. https://doi.org/10.1016/ S0305-750X(00)00098-X

Radel, C., B. Schmook, L. Carte, and S. Mardero. 2018. Toward a political ecology of migration: land, labor migration, and climate change in northwestern Nicaragua. World Development 108:263-273. https://doi.org/10.1016/j.worlddev.2017.04.023

Radel, C., B. Schmook, and C. Méndez. 2013. Gender, the household, and land change in southeastern Mexico. Pages 129-150 in C. Brannstrom and J. M. Vadjunec, editors. Land change science, political ecology, and sustainability: synergies and divergences. Routledge, Abingdon, UK.

Ramirez-Sanchez, S., and E. Pinkerton. 2009. The impact of resource scarcity on bonding and bridging social capital: the case of fishers' information-sharing networks in Loreto, BCS, Mexico. Ecology and Society 14(1):22. https://doi.org/10.5751/es-02841-140122

Ranganathan, M., and C. Balazs. 2015. Water marginalization at the urban fringe: environmental justice and urban political ecology across the North-South divide. Urban Geography 36 (3):403-423. https://doi.org/10.1080/02723638.2015.1005414

Ribot, J. C., and N. L. Peluso. 2003. A theory of access. Rural Sociology 68(2):153-181. https://doi.org/10.1111/j.1549-0831.2003. $\underline{\text { tb00133.x }}$

Rocheleau, D., B. Thomas-Slayter, and E. Wangari, editors. 1996. Feminist political ecology: global issues and local experiences. Routledge, London, UK. https://doi.org/10.4324/9780203352205

Romano, S. T. 2019. Transforming participation in water governance: the multisectoral alliances of rural water committees and NGOs in Nicaragua. International Journal of Water 
Resources Development 35(3):430-445. https://doi. org/10.1080/07900627.2017.1363722

Scott, J. C. 1998. Seeing like a state: how certain schemes to improve the human condition have failed. Yale University Press, New Haven, Connecticut, USA. https://doi.org/10.2307/j. ctvxkn7ds

Segnestam, L. 2009. Division of capitals - What role does it play for gender-differentiated vulnerability to drought in Nicaragua? Community Development 40(2):154-176. https://doi. org/10.1080/15575330903001562

Sen, A. 1984. Resources, values and development. Harvard University Press, Cambridge, Massachusetts, USA.

Shinbrot, X. A., K. W. Jones, A. Rivera-Castañeda, W. LópezBáez, and D. S. Ojima. 2019. Smallholder farmer adoption of climate-related adaptation strategies: the importance of vulnerability context, livelihood assets, and climate perceptions. Environmental Management 63:583-595. https://doi.org/10.1007/ s00267-019-01152-Z

Sibhatu, K. T., V. V. Krishna, and M. Qaim. 2015. Production diversity and dietary diversity in smallholder farm households. Proceedings of the National Academy of Sciences 112 (34):10657-10662. https://doi.org/10.1073/pnas.1510982112

Stevenson, E. G. J., A. Ambelu, B. A. Caruso, Y. Tesfaye, and M. C. Freeman. 2016. Community water improvement, household water insecurity, and women's psychological distress: an intervention and control study in Ethiopia. Plos One 11(4): e0153432. https://doi.org/10.1371/journal.pone.0153432

Sultana, F. 2011. Suffering for water, suffering from water: emotional geographies of resource access, control and conflict. Geoforum 42(2):163-172. https://doi.org/10.1016/j.geoforum.2010.12.002

Sultana, F. 2021. Political ecology 1: from margins to center. Progress in Human Geography 45(1):156-165. https://doi. org/10.1177/0309132520936751

Sundberg, J. 2017. Feminist political ecology. In D. Richardson, N. Castree, M. F. Goodchild, A. Kobayashi, W. Liu, and R. A. Marston, editors. International Encyclopedia of Geography. Wiley, Hoboken, New Jersey, USA. https://doi.org/10.1002/9781118786352.wbieg0804

Truelove, Y. 2011. (Re-)conceptualizing water inequality in Delhi, India through a feminist political ecology framework. Geoforum 42(2):143-152. https://doi.org/10.1016/j.geoforum.2011.01.004

Tucker, C. 1999. Common property design principles and development in a Honduran community. Praxis: The Fletcher Journal of Development Studies 15:47-76.

United Nations Water. 2013. Water security and the global water agenda: a UN-Water analytical brief. United Nations University, Hamilton, Canada. [online] URL: https://www.unwater.org/ publications/water-security-global-water-agenda/

Utting, P., A. Chamorro, and C. Bacon. 2014. Post-conflict reconciliation and development in Nicaragua: the role of cooperatives and collective action. UNRISD Working Paper
2014-22. United Nations Research Institute for Social Development, Geneva, Switzerland. [online] URL: http://hdl. handle.net/10419/148740

Watts, M. 2000. Political ecology. Pages 257-274 in E. Sheppard and T. J. Barnes, editors. A companion to economic geography. Blackwell, Oxford, UK. https://doi.org/10.1002/9781405166430. $\underline{\mathrm{ch} 16}$

Wilson, B. R. 2015. Reclaiming the worker's property: control grabbing, farmworkers and the Las Tunas Accords in Nicaragua. Journal of Peasant Studies 42(3-4):747-763. https://doi. org/10.1080/03066150.2014.992338

World Bank. 2018. DataBank-Nicaragua. World Bank, Washington, D.C., USA. [online] URL: https://data.worldbank. org/country/nicaragua

World Health Organization. 2011. Guidelines for drinking-water quality. Fourth edition. World Health Organization, Geneva, Switzerland. [online] URL: https://www.who.int/publications/i/ item/9789241549950

World Health Organization and United Nations Children's Fund. 2006. Core questions on drinking-water and sanitation for household surveys. World Health Organization, Geneva, Switzerland. [online] URL: https://apps.who.int/iris/bitstream/ handle/10665/43489/9789241563260 eng.pdf

Wutich, A. 2020. Water insecurity: an agenda for research and call to action for human biology. American Journal of Human Biology 32(1):e23345. https://doi.org/10.1002/ajhb.23345

Wutich, A., and A. Brewis. 2014. Food, water, and scarcity: toward a broader anthropology of resource Iinsecurity. Current Anthropology 55(4):444-468. https://doi.org/10.1086/677311

Wutich, A., W. E. Jepson, J. Stoler, P. Thomson, M. Kooy, A. Brewis, C. Staddon, and K. Meehan. 2021. A global agenda for household water security: measurement, monitoring, and management. Journal of the American Water Resources Association 57(4):530-538. https://doi.org/10.1111/1752-1688.12926

Young, S. L., G. O. Boateng, Z. Jamaluddine, J. D. Miller, E. A. Frongillo, T. B. Neilands, S. M. Collins, A. Wutich, W. E. Jepson, and J. Stoler. 2019. The Household Water InSecurity Experiences (HWISE) Scale: development and validation of a household water insecurity measure for low-income and middle-income countries. BMJ Global Health 4(5):e001750. https://gh.bmj.com/ content/4/5/e001750 https://doi.org/10.1136/bmjgh-2019-001750

Young, S. L., E. A. Frongillo, Z. Jamaluddine, H. MelgarQuiñonez, R. Pérez-Escamilla, C. Ringler, and A. Y. Rosinger. 2021. Perspective: the importance of water security for ensuring food security, good nutrition, and well-being. Advances in Nutrition 12(4):1058-1073. https://doi.org/10.1093/advances/ $\underline{\text { nmab003 }}$

Zimmerer, K. S., E. F. Lambin, and S. J. Vanek. 2018. Smallholder telecoupling and potential sustainability. Ecology and Society 23 (1):30. https://doi.org/10.5751/ES-09935-230130 